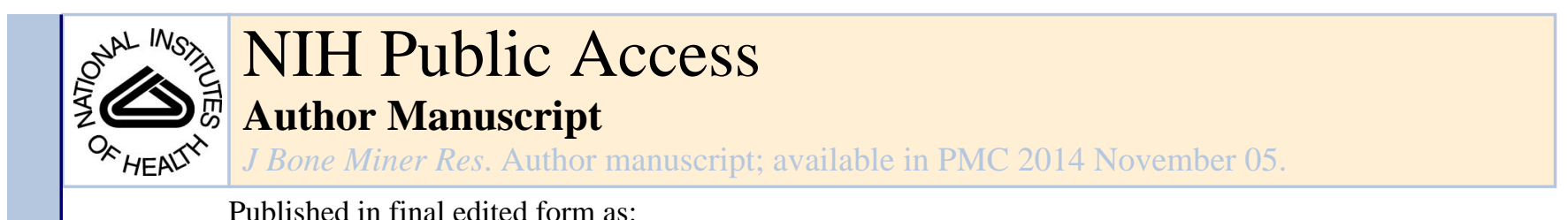

Published in final edited form as:

J Bone Miner Res. 2014 November ; 29(11): 2414-2426. doi:10.1002/jbmr.2270.

\title{
Loss of $\mathrm{G}_{\mathrm{s}} \mathrm{a}$ Early in the Osteoblast Lineage Favors Adipogenic Differentiation of Mesenchymal Progenitors and Committed Osteoblast Precursors
}

\author{
Partha Sinha $^{1}$, Piia Aarnisalo ${ }^{1,2}$, Rhiannon Chubb ${ }^{1}$, Noriaki Ono ${ }^{1}$, Keertik Fulzele ${ }^{1}$, Martin \\ Selig $^{3}$, Hamid Saeed ${ }^{4}$, Min Chen ${ }^{5}$, Lee S Weinstein ${ }^{5}$, Paola Divieti Pajevic ${ }^{1}$, Henry M \\ Kronenberg ${ }^{1}$, and Joy $\mathrm{Y} \mathbf{W u}^{1,4}$
}

${ }^{1}$ Endocrine Unit, Massachusetts General Hospital, Boston, MA, USA ${ }^{2}$ Department of Clinical Chemistry, University of Helsinki and Helsinki University Central Hospital, Hospital District of Helsinki and Uusimaa, Laboratory Services (HUSLAB), Helsinki, Finland ${ }^{3}$ Department of Pathology, Massachusetts General Hospital, Boston, MA, USA ${ }^{4}$ Division of Endocrinology, Stanford University School of Medicine, Stanford, CA, USA ${ }^{5}$ Metabolic Diseases Branch, National Institute of Diabetes and Digestive and Kidney Diseases, Bethesda, MD, USA

\begin{abstract}
In humans, aging and glucocorticoid treatment are associated with reduced bone mass and increased marrow adiposity, suggesting that the differentiation of osteoblasts and adipocytes may be coordinately regulated. Within the bone marrow, both osteoblasts and adipocytes are derived from mesenchymal progenitor cells, but the mechanisms guiding the commitment of mesenchymal progenitors into osteoblast versus adipocyte lineages are not fully defined. The heterotrimeric $\mathrm{G}$ protein subunit $\mathrm{G}_{\mathrm{s}} \mathrm{a}$ activates protein kinase A signaling downstream of several $\mathrm{G}$ protein-coupled receptors including the parathyroid hormone receptor, and plays a crucial role in regulating bone mass. Here, we show that targeted ablation of $\mathrm{G}_{\mathrm{s}} \mathrm{a}$ in early osteoblast precursors, but not in differentiated osteocytes, results in a dramatic increase in bone marrow adipocytes. Mutant mice have reduced numbers of mesenchymal progenitors overall, with an increase in the proportion of progenitors committed to the adipocyte lineage. Furthermore, cells committed to the osteoblast lineage retain adipogenic potential both in vitro and in vivo. These findings have clinical implications for developing therapeutic approaches to direct the commitment of mesenchymal progenitors into the osteoblast lineage.
\end{abstract}

(C) 2014 American Society for Bone and Mineral Research.

Address correspondence to: Joy Y Wu, MD, Stanford University School of Medicine, 300 Pasteur Drive, Room S-025, Stanford, CA 94305, USA. jywu1@ stanford.edu.

Disclosures

All authors state that they have no conflicts of interest.

Authors' roles: Study design: PS, PA, LSW, PDP, HMK, and JYW. Data collection: PS, PA, RC, NO, KF, MS, HS, MC, LSW, PDP, and JYW. Data analysis and interpretation: PS, PA, RC, KF, HS, PDP, LSW, HMK, and JYW. Drafting manuscript: PS and JYW.

Revising manuscript content: all authors. Approving final version of manuscript: all authors. JYW takes responsibility for the integrity of the data analysis.

Additional Supporting Information may be found in the online version of this article. 


\section{Keywords}

OSTEOBLASTS; GSA; MESENCHYMAL PROGENITORS; ADIPOCYTES

\section{Introduction}

Osteoporosis is a significant and growing clinical problem. More than 50\% of postmenopausal women will suffer an osteoporotic fracture in their lifetime, with estimated annual costs exceeding $\$ 19$ billion. ${ }^{(1,2)}$ Several clinical scenarios, including aging, glucocorticoid treatment, and anorexia nervosa, are all associated with decreased bone mass and enhanced bone marrow adiposity. ${ }^{(3-5)}$ Increased marrow adiposity is also found in premenopausal women with idiopathic osteoporosis, ${ }^{(6)}$ and an inverse association between vertebral bone mineral density and marrow adipocytes in healthy young adults indicates that this relationship between bone mass and marrow adiposity may occur even under physiologic conditions. ${ }^{(7)}$ A similar negative correlation between bone and fat mass has also been identified in mouse models. Mice haploinsufficient for the adipogenic transcription factor PPAR $\gamma$ exhibit impaired fat differentiation and increased bone mass, ${ }^{(8)}$ and mice with adipose tissue-specific deletion of PPAR $\gamma$ have high bone mass with decreased marrow fat. ${ }^{(9)}$

That an increase in marrow adipocytes often accompanies a decrease in bone mass suggests that the differentiation of these two lineages may be coordinated and perhaps even represent alternative fate choices for mesenchymal progenitors. The pathways governing the commitment of mesenchymal progenitors into the osteoblast and adipocyte lineages are still being investigated, but could represent clinically relevant targets for the treatment of osteoporosis. In vitro, clonally derived bone marrow stromal cells (BMSCs) can be differentiated into osteoblasts, chondrocytes, and adipocytes; these multipotent progenitors have been termed mesenchymal stem cells. ${ }^{(10)}$ Although the prospective identification, location, and function of mesenchymal stem/progenitor cells (MSPCs) are still being clarified in vivo, recent studies suggest that in the bone marrow, MSPCs occupy a perivascular location. ${ }^{(11-17)}$

Expression of the transcription factor Runx 2 is required for osteoblast differentiation. ${ }^{(18-20)}$ However, whether commitment to the osteoblast lineage is accompanied by loss of potential for differentiation into other mesenchymal lineages remains unclear. Growing evidence indicates that osteoprogenitors may retain adipogenic potential. Nuttall and colleagues reported that human primary osteoblasts expressing osteocalcin, a marker of terminally differentiation, could undergo robust adipocyte differentiation when placed in adipogenic conditions in vitro. ${ }^{(21)}$ However, lineage-tracing techniques were not available to unambiguously demonstrate that committed osteoblasts themselves became adipocytes. In further support of the possibility that preosteoblasts can become adipocytes, primary mesenchymal precursors from calvariae of mice lacking Runx 2 undergo spontaneous differentiation into adipocytes, and a side population of calvarial mesenchymal cells expresses both PPAR $\gamma$ and Runx2. ${ }^{(22,23)}$ Furthermore, expression of Runx2 in clonal bone marrow stromal cell lines does not preclude adipogenic differentiation. ${ }^{(24)}$ 
One pathway implicated in the regulation of osteoblast versus adipocyte differentiation is the canonical Wnt signaling pathway. ${ }^{(25)}$ Binding of Wnt ligands to Wnt receptors, along with Wnt co-receptors LRP5 and LRP6, leads to stabilization of $\beta$-catenin, which translocates into the nucleus to stimulate transcription of Wnt target genes. ${ }^{(26)}$ In humans, loss-of-function mutations in LRP5 lead to osteoporosis, whereas gain-of-function mutations result in high bone mass. ${ }^{(27-29)} \mathrm{Wnt}$ signaling is required for early stages of osteoblast commitment and differentiation. ${ }^{(30-32)}$ In contrast, Wnt signaling is a negative regulator of adipogenesis. ${ }^{(33)}$ Interestingly, overexpression of Wnt10b in adipocytes leads to an increase in trabecular bone, suggesting that altered Wnt signaling in the adipocyte lineage may regulate bone mass. ${ }^{(25)}$ Removal of $\beta$-catenin early in the osteoblast lineage in cells expressing the osteogenic transcription factor osterix (Osx) leads to a decrease in bone mass accompanied by an increase in marrow adipogenesis, with some adipocytes descended from Osx-expressing progenitors. ${ }^{(34)}$ More recently, lineage-tracing experiments have confirmed that Osx-expressing cells labeled during embryogenesis can give rise to both osteoblasts and adipocytes in vivo. ${ }^{(35)}$

Signaling mediated by the parathyroid hormone (PTH)/PTH-related peptide (PTHrP) receptor (PPR) is also involved in the differentiation of both osteoblasts and adipocytes. Increased signaling via the PPR owing to constitutive activation of the receptor in osteoblasts or osteocytes leads to marked increases in trabecular bone. ${ }^{(36)}$ In contrast, deletion of the ligand PTHrP results in impaired skeletal development, ${ }^{(37)}$ and haploinsufficiency of PTHrP during development results in both decreased bone mass and increased bone marrow adiposity. ${ }^{(38)}$ Because recombinant $\mathrm{PTH}(1-34)$ (teriparatide) is now in clinical use as the only available anabolic treatment for osteoporosis, ${ }^{(39)}$ there is great interest in understanding how PPR-mediated signaling results in increased bone formation. ${ }^{(40)}$ However, the effects of anabolic PTH on marrow fat are largely unexplored.

The PPR is a G protein-coupled receptor that can signal to a variety of G proteins. One major downstream mediator of PPR signaling is $\mathrm{G}_{\mathrm{s}} \mathrm{a}$, which stimulates adenylyl cyclase, increasing cyclic AMP (cAMP) levels and activating the protein kinase A (PKA)-dependent gene transcription pathway. ${ }^{(41)}$ In vitro, the constitutively active mutant PPR associated with Jansen's metaphyseal chondrodysplasia signals predominantly through $\mathrm{G}_{\mathrm{s}} \mathrm{a}$, and constitutive activation of $\mathrm{G}_{\mathrm{s}} \mathrm{a}$ also dramatically increases trabecular bone. ${ }^{(42,43)} \mathrm{In}$ contrast, marrow adipocytes are decreased in mice with the constitutively active mutant PPR targeted to osteoblasts. ${ }^{(44)}$ Likewise, somatic activating mutations of $\mathrm{G}_{\mathrm{s}} \mathrm{a}$ are associated with fibrous dysplasia, in which hematopoietic bone marrow is replaced by fibroblastoid stromal cells lacking adipocytes. ${ }^{(45)} \mathrm{G}_{\mathrm{s}} \mathrm{a}$ may also have a direct role in regulating adipogenesis, although studies have been conflicting. In 3T3-L1 preadipocyte cells, both PTHrP stimulation via PPR and constitutive expression of $\mathrm{G}_{\mathrm{s}} \mathrm{a}$ can inhibit differentiation into adipocytes. ${ }^{(46,47)} \mathrm{On}$ the other hand, adipose-derived stromal cells from mice haploinsufficient for $\mathrm{G}_{\mathrm{s}} \mathrm{a}$ exhibit impaired adipogenic differentiation, ${ }^{(48,49)}$ and in vivo ablation of $\mathrm{G}_{\mathrm{s}} \mathrm{a}$ in mature adipocytes results in a lean phenotype. ${ }^{(50)}$ There are similarly contradictory reports regarding the relevance of downstream cyclic AMP (cAMP) accumulation and PKA activation to adipogenic differentiation. ${ }^{47,51,52)}$ 
We have reported that ablation of $\mathrm{G}_{\mathrm{S}} \mathrm{a}$ early in the osteoblast lineage results in severe osteoporosis with fractures at birth. We identified inhibition of Wnt signaling owing to overexpression of Dkk1 and Sclerostin with a marked loss of osteoblast progenitors (hereafter referred to as osteoprogenitors) as one potential mechanism for the reduction in bone formation. ${ }^{(53)}$ We now demonstrate that loss of $\mathrm{G}_{\mathrm{S}} \mathrm{a}$ early in the osteoblast lineage, but not in osteocytes, also leads to a dramatic increase in the number of bone marrow adipocytes. Although a decrease in canonical Wnt signaling is accompanied by a shift of mesenchymal progenitors in favor of the adipocyte lineage, we also find that some Osxexpressing osteoprogenitors retain the potential to differentiate into adipocytes. Taken together, our data suggest that $\mathrm{G}_{\mathrm{s}} \mathrm{a}$ signaling in osteoprogenitors acts to suppress adipogenic differentiation of mesenchymal precursors via increased Wnt signaling. Moreover, we confirm the presence of bipotential osteoblast/adipocyte progenitors in vivo that represent a potential cellular target for regulating the balance between bone and fat.

\section{Materials and Methods}

\section{Mice}

$\mathrm{G}_{\mathrm{s}} \mathrm{a}^{\mathrm{OsxKO}}$ mice were generated by crossing Osx 1-GFP::Cre ${ }^{(32)}$ mice to $\mathrm{G}_{\mathrm{s}} \mathrm{a}^{\mathrm{fl} / \mathrm{fl}}$ mice ${ }^{(51)}$ as previously described. ${ }^{(54)}$ To delay ablation of $\mathrm{G}_{\mathrm{S}} \mathrm{a}$ until postnatal life, doxycycline was administered in drinking water at a dose of $10 \mu \mathrm{g} / \mathrm{mL}$ from plug until birth. ROSA26 (R26R, stock 3309) ${ }^{(55)}$ and $\mathrm{mTmG}$ reporter mice ${ }^{(56)}$ were obtained from Jackson Labs (Bar Harbor, ME, USA). Because $\mathrm{G}_{\mathrm{s}} \mathrm{a}^{\mathrm{OsxKO}}$ mice are of mixed genetic background, littermate controls $\left(\mathrm{G}_{\mathrm{s}} \mathrm{a}^{\mathrm{fl} / \mathrm{fl}}\right.$ except where otherwise specified) were used for all experiments described. Genotyping was performed on tail genomic DNA as described in the Supplemental Methods. Percent fat of the mid-diaphyseal region of the humeri and femora in 12-week-old control and $\mathrm{G}_{\mathrm{S}} \mathrm{a}$ OsxKO female mice was measured by dual-energy X-ray absorptiometry (DXA) on a Lunar Piximus (GE Medical Systems, Milwaukee, WI, USA). Eight 12-weekold mice were fed a high-fat diet (45\% kcal from fat, Harlan-Teklad TD.06415, Indianapolis, IN, USA) for 4 to 6 weeks. All animals were housed in the Center for Comparative Medicine at the Massachusetts General Hospital or by the Veterinary Services Center at Stanford University, and all experiments were approved by the respective Institutional Animal Care and Use Committees.

\section{Histology}

Mouse limbs were fixed in $10 \%$ buffered formalin, paraffin embedded, and sectioned. For toluidine blue staining, limbs were fixed in fixed in EM fixative (2.5\% glutaraldehyde, $2 \%$ paraformaldehyde [PFA], $0.025 \%$ calcium chloride in a $0.1 \mathrm{M}$ sodium cacodylate buffer [pH 7.4]).

To count adipocytes, frozen sections were air-dried, fixed with $2 \%$ PFA, rinsed in TBS-T, then incubated with LipidTox Deep Red (Invitrogen, Carlsbad, CA, USA) diluted 1:500 in PBS for 30 minutes before mounting with DAPI. Adipocytes were counted on mid-sagittal sections of tibias from at least 3 mice per genotype. Images were acquired on a Zeiss Axio Imager Z2 microscope (Carl Zeiss Microscopy, Thornwood, NY, USA) with the 
TissueFAXS system and quantitated using TissueQuest software (TissueGnostics, Tarzana, CA, USA).

\section{Tissue culture}

BMSCs were isolated from long bones by crushing in PBS, and plated at 0.5 to $1 \times 10^{6}$ cells $/ \mathrm{cm}^{2}$. Adipogenic differentiation was induced with $10^{-8} \mathrm{M}$ dexamethasone, $5 \mu \mathrm{g} / \mathrm{mL}$ insulin, and where indicated, $1 \mu \mathrm{M}$ rosiglitazone (Cayman Chemical, Ann Arbor, MI, USA). Calvarial osteoblasts were harvested by serial collagenase digestion as described in Yang and colleagues. ${ }^{(57)}$ For cellular differentiation assays, calvarial osteoblasts were plated at 5 to $10 \times 10^{3}$ cells $/ \mathrm{cm}^{2}$. For inhibition of Wnt signaling, cells were treated with $20 \mathrm{nM}$ of $\mathrm{LiCl}$ (or $\mathrm{NaCl}$ as a control) or $1 \mu \mathrm{M}$ 6-bromoindirubin-3'-oxime (BIO). All chemicals were purchased from Sigma-Aldrich (St. Louis, MO, USA) unless otherwise specified.

\section{Immunohistochemistry}

BMSCs were fixed with 2\% paraformaldehyde, washed with TBS, and permeabilized with $0.05 \%$ digitonin. Cells were blocked with $2 \%$ BSA, then incubated with anti-perilipin A antibody (Invitrogen) overnight before staining with Alexa Fluor 633-coupled secondary antibody (Invitrogen). Cells were then washed and mounted with DAPI to visualize nuclei.

\section{CFU assays}

CFU assays were performed as described in $\mathrm{Wu}$ and colleagues. ${ }^{(53)}$ Briefly, BMSCs from WT and $\mathrm{G}_{\mathrm{s}} \mathrm{a}^{\mathrm{OsxKO}}$ mice were seeded at $50 \times 10^{3}$ cells $/ \mathrm{cm}^{2}$ on Primaria cell culture plates (Falcon; Corning, Inc., Corning, NY, USA), whereas calvarial cells were seeded at 100 cells $/ \mathrm{cm}^{2}$. For colony-forming unit fibroblastic (CFU-F) assays, colonies were cultured for 7 days in a-MEM plus $10 \%$ fetal bovine serum, then fixed with formalin and stained with methylene blue. For CFU-alkaline phosphatase (ALP) assays, colonies were cultured in osteogenic media containing $10 \mathrm{mM} \beta$-glycerol phosphate and $50 \mu \mathrm{g} / \mathrm{mL}$ ascorbic acid (both from Sigma). After 7 days, colonies were fixed in formalin and stained for alkaline phosphatase activity as described. ${ }^{(58)}$ For CFU-adipocyte assays, colonies were cultured under adipogenic conditions with $10^{-8} \mathrm{M}$ dexamethasone, $5 \mu \mathrm{g} / \mathrm{mL}$ insulin, and $1 \mu \mathrm{M}$ rosiglitazone and stained with oil red $\mathrm{O}$ at day 7 .

\section{Flow cytometry}

Flow cytometric analysis for GFP expression was performed on a FACS Calibur (Becton Dickinson, Franklin Lakes, NJ, USA). Fluorescence-activated cell sorting for Osx-GFP', Coll-GFP ${ }^{+}$, and OC-GFP ${ }^{+}$cells was performed on a FACS Aria (Becton Dickinson) as described. ${ }^{(53)}$

\section{Quantitative real-time PCR}

Total RNA was isolated using the RNeasy kit (Qiagen, Valencia, CA, USA) and cDNA was synthesized with the SuperScript III First Strand synthesis system for real-time PCR (Invitrogen). Quantitative real-time PCR was performed using primers for $G_{s} a ;{ }^{(59)} P$ Parg, Fabp4, adiponectin; ${ }^{(60)}$ Cebpa, Cebpb, Cebpd, Prdm16, Elovl3, Cidea $;{ }^{(61)}$ Dlk1 and Zfp423; ${ }^{(62)}$ and Pgcla and Ucpl, ${ }^{(63)}$ according to previously published protocols, with 
mRNA levels normalized relative to $\beta$-actin expression. Primer sequences are provided in Supplemental Table S1.

\section{Statistics}

Statistical analyses were performed using a two-tailed Student's $t$ test. All values are expressed as mean \pm standard error of the mean.

\section{Results}

Ablation of $\mathrm{G}_{\mathrm{s}} \mathrm{a}$ early in the osteoblast lineage $\left(\mathrm{G}_{\mathrm{s}} \mathrm{a}^{\mathrm{OsxKO}}\right.$ mice $)$ in osterix (Osx)-expressing progenitors leads to profound osteoporosis with early postnatal fractures. ${ }^{(53)}$ Histological analysis of Osx1-GFP::Cre; $\mathrm{G}_{\mathrm{s}} \mathrm{a}^{\mathrm{fl} / \mathrm{fl}}\left(\mathrm{G}_{\mathrm{s}} \mathrm{a}^{\mathrm{OsxKO}}\right)$ mice at 2 weeks of age revealed abundant adipocytes within the secondary ossification center; in contrast, no adipocytes were found in the secondary ossification center of control littermates at this age (Fig. 1A). Although on paraffin-embedded sections no adipocytes were visible within the diaphyseal bone marrow of young $\mathrm{G}_{\mathrm{s}} \mathrm{a}^{\text {OsxKO }}$ mice (data not shown), in sections prepared for electron microscopy without xylene deparaffinization, abundant lipid was noted throughout the marrow space of mutant mice (Fig. 1B). At 2 weeks of age, there were few adipocytes in the bone marrow of control $\left(\mathrm{G}_{\mathrm{s}} \mathrm{a}^{\mathrm{fl} / \mathrm{fl}}[\mathrm{WT}]\right.$ or Osx 1-GFP::Cre; $\left.\mathrm{G}_{\mathrm{s}} \mathrm{a}^{\mathrm{fl} /+}\left[\mathrm{G}_{\mathrm{s}} \mathrm{a}^{\text {OsxHET }}\right]\right)$ tibias. In contrast, the bone marrow of $\mathrm{G}_{\mathrm{s}} \mathrm{a}$ OsxKO tibias contained significantly more adipocytes (Fig. 1C). $\mathrm{G}_{\mathrm{s}} \mathrm{a}$ OsxKO mice do not survive past weaning. ${ }^{(53)}$ However, the Osx 1-GFP::Cre construct is regulated by doxycycline, which suppresses expression of the Cre recombinase. ${ }^{(32)}$ Thus, administration of doxycycline until birth delays ablation of $\mathrm{G}_{\mathrm{s}} \mathrm{a}$ until postnatal life (P$\mathrm{G}_{\mathrm{s}} \mathrm{a}$ OsxKO mice), with resulting survival for at least 6 months. By 3 months of age, increased marrow fat as measured by DXA was evident in the long bones of $\mathrm{P}_{-} \mathrm{G}_{\mathrm{s}} \mathrm{a}^{\mathrm{OsxKO}}$ mice (Fig. $1 D$ ). At 6 months of age, there was near-complete replacement of the bone marrow with adipocytes in $\mathrm{P}-\mathrm{G}_{\mathrm{s}} \mathrm{a}$ OsxKO mice (Fig. $1 E$ ). Thus, the removal of $\mathrm{G}_{\mathrm{s}} \mathrm{a}$ from the osteoblast lineage results in severe osteoporosis accompanied by a dramatic increase in bone marrow adiposity.

To investigate the adipogenic potential of mesenchymal progenitors in $\mathrm{G}_{\mathrm{s}} \mathrm{a}^{\mathrm{OsxKO}}$ mice, we isolated BMSCs and induced adipogenesis with insulin, dexamethasone, and rosiglitazone. Adipogenic differentiation was significantly enhanced in $\mathrm{G}_{\mathrm{s}} \mathrm{a}$ OsxKO $\mathrm{BMSCs}$, as indicated by oil red O staining (Fig. 2A, B). mRNA levels of Pparg, Fabp4, and adiponectin, markers of terminal adipogenic differentiation, were increased in BMSCs from $\mathrm{G}_{\mathrm{s}} \mathrm{a}^{\mathrm{OsxKO}}$ mice, confirming more robust differentiation into the adipocyte lineage, and not simply the cellular accumulation of lipid (Fig. 2C). To determine whether any components of the transcription cascade that regulate adipogenesis are altered in $\mathrm{G}_{\mathrm{s}} \mathrm{a}$ OsxKO marrow-derived adipocytes, we measured mRNA levels of several adipogenic transcription factors. There was a significant increase in expression of Cebpa and Cebpb but not Cebpd mRNAs. mRNA levels of Zfp423, a regulator of PPAR $\gamma$ expression, ${ }^{(64)}$ were also increased (Fig. $2 D$ ).

Wnt signaling plays an important role in regulating the balance between osteogenic and adipogenic differentiation. $\mathrm{G}_{\mathrm{s}} \mathrm{a}$ OsxKO mice have increased expression of two inhibitors of canonical Wnt signaling, sclerostin and Dkk1, with a concomitant reduction in Wnt signaling in osteoblasts; this was associated with a decrease in overall mesenchymal 
progenitors and a loss of osteoblast progenitors. ${ }^{(53)}$ To examine whether altered Wnt signaling might shift the balance of osteoblast and adipocyte progenitors in the bone marrow of $\mathrm{G}_{\mathrm{s}} \mathrm{a}$ OsxKO mice, we examined the expression of Wnt target gene Lefl and found reduced mRNA levels in BMSCs isolated from mutant mice (Fig. 2E). We next performed CFU assays to quantitate the frequency of mesenchymal, osteoblast, and adipocyte progenitors in $\mathrm{G}_{\mathrm{s}} \mathrm{a}$ OsxKO marrow. As reported previously, ${ }^{(53)}$ the frequency of CFU-F mesenchymal progenitors and CFU-ALP osteoblast precursors are decreased in $\mathrm{G}_{\mathrm{s}} \mathrm{a}^{\mathrm{OsxKO}}$ mice. In contrast, the number of CFU-Adip adipocyte precursors is unchanged, resulting in an increased ratio of adipocyte precursors to osteogenic precursors (Fig. $2 F$ ). In keeping with an increased proportion of adipocyte precursors, expression of Dlk1/Prefl, a marker of preadipocytes, ${ }^{(65)}$ was increased early in adipogenic differentiation of BMSCs from $\mathrm{G}_{\mathrm{s}} \mathrm{a}$ OsxKO mice (Fig. $2 G$ ). Therefore, deletion of $\mathrm{G}_{\mathrm{s}} \mathrm{a}$ in the osteoblast lineage impairs Wnt signaling and alters the distribution of mesenchymal progenitors to favor adipocyte over osteoblast lineages. Recent reports suggest that bone marrow adipocytes express characteristics of both white and brown adipose tissue. ${ }^{(66)}$ To determine whether removal of $\mathrm{G}_{\mathrm{s}} \mathrm{a}$ from osteoprogenitors alters the potential of BMSCs for differentiation into brown adipocytes, we examined the expression of brown adipocyte markers during adipogenic differentiation (Supplemental Fig. S1). We found that expression of Pgcla, Elovl3, Ucpl, Prdm16, and Cidea all increased with adipogenic differentiation. However, with the exception of Pgcla, there was no statistically significant difference in brown fat differentiation of BMSCs from $\mathrm{G}_{\mathrm{s}} \mathrm{a}$ OsxKO mice compared with control littermates.

We have found that calvarial osteoblast preparations are 200-fold enriched in CFU-ALP osteoprogenitors compared with BMSCs (Wu and colleagues ${ }^{(53)}$ and Supplemental Table S2). To determine whether a population more enriched in cells of the osteoblast lineage might also have adipogenic potential, we harvested calvarial osteoblasts from $\mathrm{G}_{\mathrm{s}} \mathrm{a}$ OsxKO mice and subjected them to adipogenic differentiation. We found significantly enhanced adipogenic differentiation of $\mathrm{G}_{\mathrm{s}} \mathrm{a}$ OsxKO calvarial cells as demonstrated by increased oil red O staining (Fig. 3A, B). Analysis of the expression of the adipocyte markers Pparg, Fabp4, and adiponectin confirmed differentiation of calvarial cells into cells of the adipocyte lineage (Fig. $3 C$ ). As with BMSCs, in calvarial osteoblast preparations subjected to adipogenic differentiation, we detected a significant increase in Cebpa, Cebpb, and Zfp 423 mRNA levels (Fig. 3D). Again, CFU assays revealed that although CFU-F and CFU-ALP are decreased in $\mathrm{G}_{\mathrm{s}} \mathrm{O}$ OsxKO calvarial osteoblasts, CFU-Adip are preserved (Fig. $3 E$ ) and expression of the preadipocyte marker $D l k l$ is increased (Fig. $3 E, F$ ). These findings are consistent with the reduction of Wnt signaling that we have previously demonstrated in the osteoblast lineage of $\mathrm{G}_{\mathrm{S}} \mathrm{a}^{\mathrm{OsxKO}}$ mice. ${ }^{(53)}$ Therefore, in both BMSCs enriched for mesenchymal progenitors, as well as in calvarial osteoblast preparations enriched for committed osteoblast precursors, removal of $\mathrm{G}_{\mathrm{s}} \mathrm{a}$ from the osteoblast lineage leads to reduced Wnt signaling and an increase in the relative proportion of adipogenic precursors.

Because $\mathrm{G}_{\mathrm{S}}$ a has been reported to inhibit adipogenesis directly in 3T3-L1 preadipocytes, ${ }^{(47)}$ we examined whether removal of $\mathrm{G}_{\mathrm{s}}$ a has direct cell-autonomous effects to enhance adipogenic differentiation. Because calvarial cells harvested directly from control and $\mathrm{G}_{\mathrm{s}} \mathrm{a}{ }^{\mathrm{OsxKO}}$ mice have differing frequencies of mesenchymal progenitors (Fig. $3 E$ ), we plated 
calvarial osteoblast cells from $\mathrm{G}_{\mathrm{s}} \mathrm{a}^{\mathrm{fl} / \mathrm{fl}}$ mice to eliminate any differences in the distribution of mesenchymal progenitors. Cells were then infected in vitro with adenovirus-encoding Cre recombinase to ablate $\mathrm{G}_{\mathrm{s}} \mathrm{a}$ with $>90 \%$ efficiency. ${ }^{(53)}$ There was no difference in adipogenic differentiation between the control and $\mathrm{G}_{\mathrm{s}} \mathrm{a}$-deficient cells (Supplemental Fig. S2A, B). Analysis of mRNA confirmed efficient deletion of $\mathrm{G}_{\mathrm{s}} \mathrm{a}$ and no change in expression of terminal markers of adipogenic differentiation Pparg and Fabp4 (Supplemental Fig. S2C).

Thus, when calvarial cells are harvested from mice with normal $\mathrm{G}_{\mathrm{s}} \mathrm{a}$ function in osteoblastic cells, with subsequent ablation of $\mathrm{G}_{\mathrm{s}} \mathrm{a}$ in vitro, we find no additional effect of removal of $\mathrm{G}_{\mathrm{s}} \mathrm{a}$ on adipogenesis. This indicates that ablation of $\mathrm{G}_{\mathrm{s}} \mathrm{a}$ in the osteoblast lineage likely causes enhanced adipogenesis in large part by altering the distribution of mesenchymal progenitors in vivo.

Signaling downstream of PPR has been reported to intersect directly with Wnt signaling in cells. ${ }^{(67-71)} \mathrm{We}$, therefore, examined whether $\mathrm{G}_{\mathrm{s}} \mathrm{a}$ is required for Wnt-mediated inhibition of adipogenesis. Control and $\mathrm{G}_{\mathrm{s}} \mathrm{a}$-deficient cells were subjected to adipogenic differentiation in the presence of lithium chloride $(\mathrm{LiCl})$ and 6-bromoindirubin-3'-oxime (BIO), pharmacologic activators of Wnt signaling. Inhibition of adipogenesis was similar in control and $\mathrm{G}_{\mathrm{S}} \mathrm{a}$-deficient calvarial cells (Supplemental Fig. S2D), and although expression of the Wnt target gene Axin2 is reduced in $\mathrm{G}_{\mathrm{s}} \mathrm{a}$-deficient cells, addition of $\mathrm{LiCl}$ markedly upregulated Axin2 expression in both control and $\mathrm{G}_{\mathrm{s}} \mathrm{a}$-deficient cells (Supplemental Fig. $\mathrm{S} 2 E$ ). Therefore, $\mathrm{G}_{\mathrm{s}} \mathrm{a}$ expression is not required for Wnt-mediated inhibition of adipogenic differentiation.

Because Osx-expressing cells can give rise to adipocytes, ${ }^{(34,35)}$ we performed lineage tracing experiments to determine whether any adipocytes in $\mathrm{G}_{\mathrm{s}} \mathrm{a}$ OsxKO mice might be derived from osteoprogenitors lacking $\mathrm{G}_{\mathrm{s}} \mathrm{a}$. Osx 1-GFP::Cre; $\mathrm{G}_{\mathrm{s}} \mathrm{a}^{+/+}\left(\mathrm{G}_{\mathrm{s}} \mathrm{a}^{\mathrm{OsxWT}}\right)$, $\mathrm{G}_{\mathrm{s}} \mathrm{a}^{\text {OsxHET }}$, and $\mathrm{G}_{\mathrm{s}} \mathrm{a}^{\mathrm{OsxKO}}$ mice were crossed to $\mathrm{mTmG}$ reporter mice, in which cells express red fluorescence at baseline (in the absence of Cre recombinase), and green fluorescence when Cre recombinase has been activated. ${ }^{(56)} \mathrm{BMSCs}$ from $\mathrm{G}_{\mathrm{s}} \mathrm{a}^{\mathrm{OsxWT}} ; \mathrm{mTmG}$, $\mathrm{G}_{\mathrm{s}} \mathrm{a}^{\mathrm{OsxHET}} ; \mathrm{mTmG}$, and $\mathrm{G}_{\mathrm{s}} \mathrm{a}^{\text {OsxKO}} ; \mathrm{mTmG}$ mice were differentiated under adipogenic conditions. Differentiation into terminal adipocytes was confirmed by costaining with LipidTox, a neutral lipid stain, and perilipin, a marker of mature adipocytes ${ }^{(72)}$ (Fig. 4A). The presence of perilipin ${ }^{+}$adipocytes that were also $\mathrm{GFP}^{+}$confirmed that Osx-expressing precursors can become adipocytes (Fig. 4B). As expected, the frequency of total adipocytes was increased in cultured BMSCs from $\mathrm{G}_{\mathrm{s}} \mathrm{a}^{\mathrm{OsxKO}}$ mice compared with either $\mathrm{G}_{\mathrm{s}} \mathrm{a}^{\mathrm{OsxWT}}$ and $\mathrm{G}_{\mathrm{s}} \mathrm{a}^{\mathrm{OsxHET}}$ mice (Fig. $4 C$ ). The majority of adipocytes were red, indicating that although Osx-expressing cells from BMSCs can become adipocytes, most bone marrow-derived adipocytes in vitro are descended from cells not expressing Osx (Fig. 4C). Consistent with our previous finding that mesenchymal progenitors and osteoprogenitors are reduced in frequency in $\mathrm{G}_{\mathrm{s}} \mathrm{a}$ OsxKO mice (Wu and colleagues ${ }^{(53)}$ and Fig. $2 F$ ), we found a significant decrease in the frequency of total Osx-expressing cells (Fig. 4D). Within the Osx-expressing cells, although the frequency of adipocytes was increased among BMSCs from $\mathrm{G}_{\mathrm{s}} \mathrm{a}$ OsxKO mice, this did not reach statistical significance (data not shown).

To examine the adipogenic potential of more differentiated osteoblast precursors, we used fluorescence-activated cell sorting (FACS) to harvest Osx-GFP+ ${ }^{+}$cells from calvarial 
osteoblast preparations (Fig. 5A). When these cells were plated and subjected to adipogenic differentiation, we identified oil red O-stained cells (Fig. $5 B$ ). We next crossed $\mathrm{G}_{\mathrm{s}} \mathrm{a}$ OsxKO mice to the R26-LacZ reporter mice, ${ }^{(55)}$ isolated calvarial osteoblasts, and subjected them to adipogenic differentiation in culture. Staining with X-gal identified blue cells that had expressed Cre recombinase and also stained with oil red $\mathrm{O}$, demonstrating that even in more differentiated osteoblast lineage cells harvested from calvariae, cells descended from Osxexpressing precursors can become adipocytes (Fig. 5C). To quantitate the frequency of adipogenic differentiation, we harvested calvarial osteoblasts from $\mathrm{G}_{\mathrm{s}} \mathrm{a}^{\mathrm{OsxHET}} ; \mathrm{mTmG}$ and $\mathrm{G}_{\mathrm{s}} \mathrm{a}^{\mathrm{OsxKO}} ; \mathrm{mTmG}$ mice. $\mathrm{G}_{\mathrm{s}} \mathrm{a}^{\text {OsxHET}}$;mTmG were used as controls because they are similar to $\mathrm{G}_{\mathrm{s}} \mathrm{a}^{\mathrm{OsxWT}}$;mTmG mice (Fig. $1 C$ and Fig. $4 C, D$ ) and are more abundantly available as littermate controls to $\mathrm{G}_{\mathrm{s}} \mathrm{a}^{\mathrm{OsxKO}}$;mTmG mice. As with BMSCs, we identified $\mathrm{GFP}^{+}$ adipocytes derived from Osx-expressing precursors (Fig. 5D). Again, the frequency of total adipocytes was increased in cultured calvarial cells from $\mathrm{G}_{\mathrm{s}} \mathrm{a}$ OsxKO mice compared with $\mathrm{G}_{\mathrm{s}} \mathrm{a}$ OsxHET mice, with an increase in adipocytes derived from both Osx-expressing (green) and non-Osx-expressing (red) cells (Fig. 5E).

To determine whether adipogenic potential is lost as osteoprogenitors mature into osteoblasts, we harvested $\mathrm{GFP}^{+}$cells from mice that express GFP in maturing osteoblasts (Col2.3:: GFP mice $\left.{ }^{(73)}\right)$ and terminally differentiated osteoblasts (OC::GFP mice $\left.{ }^{(74)}\right)$. GFP $^{+}$ and $\mathrm{GFP}^{-}$cells from each transgenic line were subjected to adipogenic differentiation. Although rare oil red $\mathrm{O}^{+}$were identified among Col2.3::GFP+ $\mathrm{Gells}^{+}$, almost no adipocytes were found within the OC:: $\mathrm{GFP}^{+}$fraction (Fig. $5 F$ ). Thus, although Osx-expressing osteoprogenitors can become adipocytes in vitro, this adipogenic capacity is progressively lost as cells differentiate toward mature osteoblasts.

To investigate whether Osx-expressing osteoprogenitors give rise to adipocytes in vivo, we performed X-gal staining on hind-limb sections from $\mathrm{G}_{\mathrm{s}} \mathrm{a}^{\mathrm{OsxWT}} ; \mathrm{R} 26$ and $\mathrm{G}_{\mathrm{s}} \mathrm{a}^{\mathrm{OsxKO}} ; \mathrm{R} 26$ mice. As expected, blue osteoblasts and osteocytes were identified in $\mathrm{G}_{\mathrm{s}} \mathrm{a}^{\mathrm{OsxWT}} ; \mathrm{R} 26$ and $\mathrm{G}_{\mathrm{S}} \mathrm{a}^{\mathrm{OsxKO}} ; \mathrm{R} 26$ mice. ${ }^{(53)}$ In addition, blue staining was noted within adipocyte ghosts in $\mathrm{G}_{\mathrm{s}} \mathrm{a}^{\mathrm{OsxKO}} ; \mathrm{R} 26$ marrow (Fig. $6 A$ ). Because deparaffinization in xylene dissolves lipids, we performed frozen sections on $\mathrm{G}_{\mathrm{s}} \mathrm{a}^{\mathrm{OsxHET}} ; \mathrm{mTmG}$ and $\mathrm{G}_{\mathrm{s}} \mathrm{a}^{\mathrm{OsxKO}} ; \mathrm{mTmG}$ mice. In these mice, the Cre recombinase is fused to GFP, ${ }^{(32)}$ so GFP expression will mark both cells actively expressing Osx-GFP (owing to Osx 1-GFP::Cre) as well as descendants of Osx-expressing cells (from Cre-mediated activation of mGFP expression). We have found that Osx-GFP expression is rare in bone marrow of $\mathrm{G}_{\mathrm{s}} \mathrm{a}^{\text {OsxKO }}$ mice (Wu and colleagues ${ }^{(54)}$ and Supplemental Fig. S3). Therefore, $\mathrm{GFP}^{+}$cells in the bone marrow of $\mathrm{G}_{\mathrm{s}} \mathrm{a}^{\mathrm{OsxHET}} ; \mathrm{mTmG}$ and $\mathrm{G}_{\mathrm{s}} \mathrm{a}^{\mathrm{OsxKO}} ; \mathrm{mTmG}$ mice likely represent descendants of Osx-expressing cells. In the bone marrow of $\mathrm{G}_{\mathrm{s}} \mathrm{a}^{\mathrm{OsxKO}} ; \mathrm{mTmG}$ mice, we could identify LipidTox ${ }^{+}$adipocytes, of which a significant number were green (Fig. 6B), confirming that Osx-expressing osteoprogenitors can give rise to adipocytes in vivo. Again, the number of both red and green adipocytes is significantly increased in $\mathrm{G}_{\mathrm{s}} \mathrm{a}^{\mathrm{OsxKO}}$; $\mathrm{mTmG}$ mice (Fig. $6 \mathrm{C}$ ). There is a trend toward an increased proportion of $\mathrm{GFP}^{+}$adipocytes in $\mathrm{G}_{\mathrm{s}} \mathrm{a}$ OsxKO mice, with $23.5 \pm 5.0 \%$ of adipocytes in $\mathrm{G}_{\mathrm{s}} \mathrm{a}^{\text {OsxHET }}$; $\mathrm{mTmG}$ and $39.0 \pm 6.7 \%$ of adipocytes in $\mathrm{G}_{\mathrm{s}} \mathrm{a}$ OsxKO; $\mathrm{mTmG}$ mice derived from Osx-expressing precursors, demonstrating that a significant proportion of adipocytes in vivo are derived from osteoprogenitors. 
Marrow adipocytes are rare in early postnatal control mice. To determine whether Osxexpressing osteoprogenitors can give rise to adipocytes in control mice not lacking $\mathrm{G}_{\mathrm{s}} \mathrm{a}$ in the osteoblast lineage, we placed $\mathrm{G}_{\mathrm{s}} \mathrm{a}^{\mathrm{OsxWT}}$; $\mathrm{mTmG}$ and $\mathrm{G}_{\mathrm{s}} \mathrm{a}$ OsxHET; $\mathrm{mTmG}$ mice on a highfat diet to promote bone marrow adipocyte formation. Bone marrow adiposity was significantly increased in mice fed a high-fat diet (Fig. 6D). Consistent with previous reports, ${ }^{(34,35)}$ lineage tracing of adipocytes in mice fed a high-fat diet demonstrated that even in control mice, adipocytes can be derived from Osx-expressing precursors (Fig. 6E).

Ablation of $\mathrm{G}_{\mathrm{s}} \mathrm{a}$ in osteoprogenitors leads to increased levels of sclerostin, a potent inhibitor of canonical Wnt signaling and a promising target for osteoporosis therapy. ${ }^{(53,75,76)}$

Sclerostin is produced by osteocytes, cells derived from terminally differentiated osteoblasts and surrounded by mineralized matrix. Removal of $\mathrm{G}_{\mathrm{s}} \mathrm{a}$ from osteocytes using Dmp1-driven Cre recombinase $\left(\mathrm{G}_{\mathrm{s}} \mathrm{a}^{\text {Dmp1KO }}\right.$ mice) also results in decreased bone mass and upregulation of sclerostin. ${ }^{(77)}$ To examine whether increased sclerostin expression in osteocytes is sufficient to alter the balance of bone and marrow fat, we performed histological and DXA analyses on older adult $\mathrm{G}_{\mathrm{S}} \mathrm{a}$ Dmp1KO mice and controls. By 5 months of age, marrow adipocytes are abundant in the distal tibias of control mice. In contrast, $\mathrm{G}_{\mathrm{s}} \mathrm{a}$ Dmp1KO mice instead have a marked decrease in BM adipocytes (Fig. 7A, $B$ ). Therefore, the increased expression of sclerostin by osteocytes that results from osteocyte-specific deletion of $\mathrm{G}_{\mathrm{s}} \mathrm{a}$ is not sufficient to increase BM adiposity.

\section{Discussion}

Although increased marrow adiposity is frequently found in association with reduced bone mass, the clinical significance of this finding is unknown. In patients with anorexia nervosa, recovery of healthy weight is accompanied by increased bone mass and a reduction of marrow fat. ${ }^{(78)}$ Even less is known about the effect of osteoporosis treatments on marrow fat. In one model of increased marrow fat in rodents induced by hypophysectomy, administration of growth hormone but not PTH reversed the accumulation of adipocytes. ${ }^{(79)}$ We have extended our understanding of signaling pathways regulating the commitment of mesenchymal progenitors into osteoblast and adipocyte line-ages. Ablation of $\mathrm{G}_{\mathrm{s}} \mathrm{a}$ in early osteoblast progenitors leads to a dramatic increase in bone marrow adipogenesis, attributable at least in part to a shift in favor of adipocyte progenitors within the bone marrow. Canonical Wnt signaling has been shown to favor osteoblast over adipocyte lineage commitment, and $\mathrm{G}_{\mathrm{s}} \mathrm{a}^{\mathrm{OsxKO}}$ mice have increased expression of the canonical Wnt pathway inhibitors sclerostin and Dkk1 in the osteoblast lineage with reduced Wnt signaling. ${ }^{(53)}$

Interestingly, ablation of $\mathrm{G}_{\mathrm{s}} \mathrm{a}$ in osteocytes also increases sclerostin expression, yet does not result in increased marrow fat. Therefore, it is unlikely that elevated sclerostin levels alone can explain the shift in the distribution of mesenchymal progenitors found in $\mathrm{G}_{\mathrm{s}} \mathrm{a}$ OsxKO mice, despite the inhibitory effects of sclerostin on Wnt signaling. Inhibition of Wnt signaling by sclerostin may have different effects from loss of $\beta$-catenin, the transcriptional mediator of canonical Wnt signaling. In support of a cell-autonomous role for Wnt signaling in the regulation of osteoblast versus adipocyte commitment, Song and colleagues have found that ablation of $\beta$-catenin in Osx-expressing cells also leads to increased marrow adipogenesis. ${ }^{(34)}$ Although PTH potently suppresses both sclerostin and Dkk1, ${ }^{(71,80,81)}$ PTH 
can activate $\beta$-catenin even in the absence of Dkk1 suppression, ${ }^{(71,82)}$ so PTH (and $\mathrm{G}_{\mathrm{s}} \mathrm{a}$ ) may also have actions on the Wnt pathway independent of sclerostin suppression. In addition, signaling downstream of the PPR has been shown to intersect Wnt signaling at other points. ${ }^{(67-69)}$ In particular, PKA has been demonstrated to have direct effects on Wnt signaling, for instance, via phosphorylation of $\beta$-catenin. ${ }^{(70,71)}$ However, we found that loss of $\mathrm{G}_{\mathrm{S}} \mathrm{a}$ does not affect the ability of Wnt signaling to inhibit adipogenic differentiation of osteoprogenitors. The knockdown of elevated sclerostin expression will, therefore, be informative regarding the relative contribution of sclerostin-mediated inhibition of Wnt signaling to the increased marrow adipogenesis in $\mathrm{G}_{\mathrm{s}} \mathrm{a}^{\mathrm{OsxKO}}$ mice.

Independent of effects mediated by Wnt signaling, $\mathrm{G}_{\mathrm{s}} \mathrm{a}$ may also exert direct effects on adipogenesis. Studies have suggested that PTH, PKA, and $\mathrm{G}_{\mathrm{S}}$ a have an inhibitory effect on adipogenic differentiation of 3T3-L1 preadipocytes, although the downstream mediators have not been clarified. ${ }^{(46,47,52)}$ Strikingly, when $\mathrm{G}_{\mathrm{S}} \mathrm{a}$ is deleted in mature adipocytes, the resulting mutant mice exhibit a lean phenotype, ${ }^{(50)}$ suggesting that the roles of $\mathrm{G}_{\mathrm{S}} \mathrm{a}$ in regulating adipogenesis may differ in early versus later stages of adipogenic differentiation. We did not find an increase in adipogenesis overall when $\mathrm{G}_{\mathrm{S}} \mathrm{a}$ was uniformly ablated in calvarial osteoblast preparations in vitro. However, such populations are heterogeneous, containing nonosteoblast lineage cells such as fibroblasts and hematopoietic cells. Future studies will address whether $\mathrm{G}_{\mathrm{s}} \mathrm{a}$ functions to regulate adipogenesis only in osteoprogenitors.

Adipocytes differentiated from $\mathrm{G}_{\mathrm{s}} \mathrm{a}^{\mathrm{OsxKO}} \mathrm{BMSCs}$ or calvarial osteoblast lineage cells expressed higher levels of the adipogenic transcription factors $\mathrm{C} / \mathrm{EBPa}, \mathrm{C} / \mathrm{EBP} \beta$, and Zfp423 relative to adipocytes differentiated from controls. Although the actions of C/EBPa and $\mathrm{C} / \mathrm{EBP} \beta$ on increasing transcription of PEPCK in the liver are responsive to cyclic AMP, ${ }^{(83)}$ whether $\mathrm{C} / \mathrm{EBPa}, \mathrm{C} / \mathrm{EBP} \beta$, and/or Zfp423 are themselves transcriptional targets of PKA remains to be determined. In addition, Liu and colleagues have recently reported that deletion of VEGF in osterix-expressing precursors leads to a shift in favor of adipogenic differentiation, perhaps mediated by intracrine effects of VEGF on the balance of Runx2 and PPAR $\gamma .{ }^{(84)}$ Because PTH can stimulate VEGF expression by endothelial cells, ${ }^{(85)}$ VEGF may be another target for $\mathrm{G}_{\mathrm{S}} \mathrm{a}$ in determining the balance between osteogenesis and adipogenesis.

Because the expansion of marrow adipocytes occurs as a consequence of deleting $\mathrm{G}_{\mathrm{S}} \mathrm{a}$ in the osteoblast lineage, we investigated whether cells committed to the osteoblast lineage retain adipogenic potential as previously reported, ${ }^{(34,35)}$ and also find that Osx-expressing osteoprogenitors can become adipocytes in vivo and in vitro. BMSCs from $\mathrm{G}_{\mathrm{s}} \mathrm{a}^{\mathrm{OsxKO}}$ mice exhibit enhanced adipogenic differentiation, and lineage-tracing experiments confirmed that adipocytes can differentiate from mesenchymal progenitors expressing Osx. We have further demonstrated that committed osteoprogenitors isolated from calvariae of $\mathrm{G}_{\mathrm{s}} \mathrm{a}^{\mathrm{OsxKO}}$ mice can also give rise to adipocytes. However, the adipogenic potential of mature and terminally differentiated osteoblasts is greatly restricted. Because increased marrow adipogenesis frequently accompanies loss of bone mass in humans, this finding is of significant clinical relevance, as therapeutic agents might be identified to promote osteoblast differentiation over adipogenesis. Such therapies would have potential benefit in the treatment of 
osteoporosis associated with aging and glucocorticoid treatment. It is important to note that although the differentiation of marrow stromal cells into adipocytes has been used to study adipogenesis, marrow adipocytes are distinct from peripheral fat depots, ${ }^{(86)}$ and marrow fat mass does not always correlate with peripheral fat mass, as in patients with anorexia nervosa. ${ }^{(3)}$ However, some of the key pathways critical to adipogenic differentiation are similar.

In summary, we demonstrate that loss of $\mathrm{G}_{\mathrm{s}} \mathrm{a}$-dependent signaling early in the osteoblast lineage results in a dramatic expansion of marrow adipocytes. The balance between osteogenic and adipogenic lineage commitment of mesenchymal progenitors is shifted to favor the adipocyte lineage, perhaps because of altered Wnt signaling or other actions of $\mathrm{G}_{\mathrm{s}} \mathrm{a}$ within the bone marrow milieu. We also find that Osx-expressing precursors from both bone marrow and calvarial cell preparations, thought to represent committed osteoprogenitors, retain the capacity to differentiate into adipocytes; however, this capacity is lost with progressive osteogenic differentiation. The finding that signaling downstream of GPCRs plays a critical role in determining bone and marrow fat mass presents an opportunity for the development of novel therapies for skeletal and metabolic disorders.

\section{Supplementary Material}

Refer to Web version on PubMed Central for supplementary material.

\section{Acknowledgments}

The authors thank Dr Andrew McMahon for providing Osx1-GFP:: Cre mice; Dr David Rowe for providing Col2.3::GFP and OC::GFP transgenic mice; the MGH Center for Comparative Medicine and Stanford University Veterinary Services Center staff for care of the animals; the Harvard Stem Cell Institute flow cytometry core; and the Ragon Institute imaging core.

This work was supported by the MGH Executive Committee on Research (JYW), the Harvard Stem Cell Institute (JYW), and National Institutes of Health grants AR054741 and AR059942 to JYW; Ruth Kirschstein NRSA to PS; DK11794 to HMK; AR060211 to PDP; and by the National Institute of Diabetes and Digestive and Kidney Diseases Intramural Research Program (MC and LSW).

\section{References}

1. Burge R, Dawson-Hughes B, Solomon DH, Wong JB, King A, Tosteson A. Incidence and economic burden of osteoporosis-related fractures in the United States, 2005-2025. J Bone Miner Res. 2007; 22:465-75. [PubMed: 17144789]

2. Finkelstein EA, Trogdon JG, Cohen JW, Dietz W. Annual medical spending attributable to obesity: payer-and service-specific estimates. Health Aff (Millwood). 2009; 28:w822-31. [PubMed: 19635784]

3. Bredella MA, Fazeli PK, Miller KK, Misra M, Torriani M, Thomas BJ, et al. Increased bone marrow fat in anorexia nervosa. J Clin Endocrinol Metab. 2009; 94:2129-36. [PubMed: 19318450]

4. Rosen CJ, Bouxsein ML. Mechanisms of disease: is osteoporosis the obesity of bone? Nat Clin Pract Rheumatol. 2006; 2:35-43. [PubMed: 16932650]

5. Yeung DK, Griffith JF, Antonio GE, Lee FK, Woo J, Leung PC. Osteoporosis is associated with increased marrow fat content and decreased marrow fat unsaturation: a proton MR spectroscopy study. J Magn Reson Imaging. 2005; 22:279-85. [PubMed: 16028245]

6. Cohen A, Dempster DW, Stein EM, et al. Increased marrow adiposity in premenopausal women with idiopathic osteoporosis. J Clin Endocrinol Metab. 2012; 97:2782-91. [PubMed: 22701013] 
7. Di Iorgi N, Rosol M, Mittelman SD, Gilsanz V. Reciprocal relation between marrow adiposity and the amount of bone in the axial and appendicular skeleton of young adults. J Clin Endocrinol Metab. 2008; 93:2281-6. [PubMed: 18381577]

8. Akune T, Ohba S, Kamekura S, et al. PPARgamma insufficiency enhances osteogenesis through osteoblast formation from bone marrow progenitors. J Clin Invest. 2004; 113:846-55. [PubMed: 15067317]

9. Wang F, Mullican SE, Dispirito JR, Peed LC, Lazar MA. Lipoatrophy and severe metabolic disturbance in mice with fat-specific deletion of PPARgamma. Proc Natl Acad Sci USA. 2013; 110:18656-61. [PubMed: 24167256]

10. Pittenger MF, Mackay AM, Beck SC, et al. Multilineage potential of adult human mesenchymal stem cells. Science. 1999; 284:143-7. [PubMed: 10102814]

11. Ding L, Morrison SJ. Haematopoietic stem cells and early lymphoid progenitors occupy distinct bone marrow niches. Nature. 2013; 495:231-5. [PubMed: 23434755]

12. Ding L, Saunders TL, Enikolopov G, Morrison SJ. Endothelial and perivascular cells maintain haematopoietic stem cells. Nature. 2012; 481:457-62. [PubMed: 22281595]

13. Greenbaum A, Hsu YM, Day RB, et al. CXCL12 in early mesenchymal progenitors is required for haematopoietic stem-cell maintenance. Nature. 2013; 495:227-30. [PubMed: 23434756]

14. Mendez-Ferrer S, Michurina TV, Ferraro F, et al. Mesenchymal and haematopoietic stem cells form a unique bone marrow niche. Nature. 2010; 466:829-34. [PubMed: 20703299]

15. Panaroni C, Tzeng YS, Saeed H, Wu JY. Mesenchymal progenitors and the osteoblast lineage in bone marrow hematopoietic niches. Curr Osteoporos Rep. 2014; 12:22-32. [PubMed: 24477415]

16. Park D, Spencer JA, Koh BI, et al. Endogenous bone marrow MSCs are dynamic, fate-restricted participants in bone maintenance and regeneration. Cell Stem Cell. 2012; 10:259-72. [PubMed: 22385654]

17. Sacchetti B, Funari A, Michienzi S, et al. Self-renewing osteoprogenitors in bone marrow sinusoids can organize a hematopoietic microenvironment. Cell. 2007; 131:324-36. [PubMed: 17956733]

18. Ducy P, Zhang R, Geoffroy V, Ridall AL, Karsenty G. Osf2/Cbfa1: a transcriptional activator of osteoblast differentiation. Cell. 1997; 89:747-54. [PubMed: 9182762]

19. Komori T, Yagi H, Nomura S, et al. Targeted disruption of Cbfa1 results in a complete lack of bone formation owing to maturational arrest of osteoblasts. Cell. 1997; 89:755-64. [PubMed: 9182763]

20. Otto F, Thornell AP, Crompton T, et al. Cbfa1, a candidate gene for cleidocranial dysplasia syndrome, is essential for osteoblast differentiation and bone development. Cell. 1997; 89:765-71. [PubMed: 9182764]

21. Nuttall ME, Patton AJ, Olivera DL, Nadeau DP, Gowen M. Human trabecular bone cells are able to express both osteoblastic and adipocytic phenotype: implications for osteopenic disorders. $\mathrm{J}$ Bone Miner Res. 1998; 13:371-82. [PubMed: 9525337]

22. Kobayashi H, Gao Y, Ueta C, Yamaguchi A, Komori T. Multilineage differentiation of Cbfa1deficient calvarial cells in vitro. Biochem Biophys Res Commun. 2000; 273:630-6. [PubMed: 10873656]

23. Yoshiko Y, Oizumi K, Hasegawa T, et al. A subset of osteoblasts expressing high endogenous levels of PPARgamma switches fate to adipocytes in the rat calvaria cell culture model. PLoS One. 2010; 5:e11782. [PubMed: 20668686]

24. Satomura K, Krebsbach P, Bianco P, Gehron Robey P. Osteogenic imprinting upstream of marrow stromal cell differentiation. J Cell Biochem. 2000; 78:391-403. [PubMed: 10861838]

25. Bennett CN, Longo KA, Wright WS, et al. Regulation of osteoblastogenesis, bone mass by Wnt10b. Proc Natl Acad Sci USA. 2005; 102:3324-9. [PubMed: 15728361]

26. Clevers H. Wnt/beta-catenin signaling in development and disease. Cell. 2006; 127:469-80. [PubMed: 17081971]

27. Boyden LM, Mao J, Belsky J, et al. High bone density due to a mutation in LDL-receptor-related protein 5. N Engl J Med. 2002; 346:1513-21. [PubMed: 12015390]

28. Gong Y, Slee RB, Fukai N, et al. LDL receptor-related protein 5 (LRP5) affects bone accrual and eye development. Cell. 2001; 107:513-23. [PubMed: 11719191] 
29. Little RD, Carulli JP, Del Mastro RG, et al. A mutation in the LDL receptor-related protein 5 gene results in the autosomal dominant high-bone-mass trait. Am J Hum Genet. 2002; 70:11-9. [PubMed: 11741193]

30. Day TF, Guo X, Garrett-Beal L, Yang Y. Wnt/beta-catenin signaling in mesenchymal progenitors controls osteoblast and chondrocyte differentiation during vertebrate skeletogenesis. Dev Cell. 2005; 8:739-50. [PubMed: 15866164]

31. Hill TP, Spater D, Taketo MM, Birchmeier W, Hartmann C. Canonical Wnt/beta-catenin signaling prevents osteoblasts from differentiating into chondrocytes. Dev Cell. 2005; 8:727-38. [PubMed: 15866163]

32. Rodda SJ, McMahon AP. Distinct roles for Hedgehog and canonical Wnt signaling in specification, differentiation and maintenance of osteoblast progenitors. Development. 2006; 133:3231-44. [PubMed: 16854976]

33. Ross SE, Hemati N, Longo KA, et al. Inhibition of adipogenesis by Wnt signaling. Science. 2000; 289:950-3. [PubMed: 10937998]

34. Song L, Liu M, Ono N, Bringhurst FR, Kronenberg HM, Guo J. Loss of wnt/beta-catenin signaling causes cell fate shift of preosteoblasts from osteoblasts to adipocytes. J Bone Miner Res. 2012; 27:2344-58. [PubMed: 22729939]

35. Liu Y, Strecker S, Wang L, et al. Osterix-cre labeled progenitor cells contribute to the formation and maintenance of the bone marrow stroma. PLoS One. 2013; 8:e71318. [PubMed: 23951132]

36. Calvi LM, Sims NA, Hunzelman JL, et al. Activated parathyroid hormone/parathyroid hormonerelated protein receptor in osteoblastic cells differentially affects cortical and trabecular bone. J Clin Invest. 2001; 107:277-86. [PubMed: 11160151]

37. Karaplis AC, Luz A, Glowacki J, et al. Lethal skeletal dysplasia from targeted disruption of the parathyroid hormone-related peptide gene. Genes Dev. 1994; 8:277-89. [PubMed: 8314082]

38. Amizuka N, Karaplis AC, Henderson JE, et al. Haploinsufficiency of parathyroid hormone-related peptide (PTHrP) results in abnormal postnatal bone development. Dev Biol. 1996; 175:166-76. [PubMed: 8608863]

39. Neer RM, Arnaud CD, Zanchetta JR, et al. Effect of parathyroid hormone (1-34) on fractures and bone mineral density in postmenopausal women with osteoporosis. N Engl J Med. 2001; 344:1434-41. [PubMed: 11346808]

40. Jilka RL. Molecular and cellular mechanisms of the anabolic effect of intermittent PTH. Bone. 2007; 40:1434-46. [PubMed: 17517365]

41. Weinstein LS, Yu S, Warner DR, Liu J. Endocrine manifestations of stimulatory G protein alphasubunit mutations and the role of genomic imprinting. Endocr Rev. 2001; 22:675-705. [PubMed: $11588148]$

42. Hsiao EC, Boudignon BM, Chang WC, et al. Osteoblast expression of an engineered Gs-coupled receptor dramatically increases bone mass. Proc Natl Acad Sci USA. 2008; 105:1209-14. [PubMed: 18212126]

43. Schipani E, Kruse K, Juppner H. A constitutively active mutant PTH-PTHrP receptor in Jansentype metaphyseal chondrodysplasia. Science. 1995; 268:98-100. [PubMed: 7701349]

44. Kuznetsov SA, Riminucci M, Ziran N, et al. The interplay of osteogenesis and hematopoiesis: expression of a constitutively active PTH/PTHrP receptor in osteogenic cells perturbs the establishment of hematopoiesis in bone and of skeletal stem cells in the bone marrow. J Cell Biol. 2004; 167:1113-22. [PubMed: 15611335]

45. Piersanti S, Remoli C, Saggio I, et al. Transfer, analysis, and reversion of the fibrous dysplasia cellular phenotype in human skeletal progenitors. J Bone Miner Res. 2010; 25:1103-16. [PubMed: 19874199]

46. Chan GK, Deckelbaum RA, Bolivar I, Goltzman D, Karaplis AC. PTHrP inhibits adipocyte differentiation by down-regulating PPAR gamma activity via a MAPK-dependent pathway. Endocrinology. 2001; 142:4900-9. [PubMed: 11606458]

47. Wang HY, Watkins DC, Malbon CC. Antisense oligodeoxynucleotides to GS protein alpha-subunit sequence accelerate differentiation of fibroblasts to adipocytes. Nature. 1992; 358:334-7. [PubMed: 1379345] 
48. Liu JJ, Russell E, Zhang D, Kaplan FS, Pignolo RJ, Shore EM. Paternally inherited gsalpha mutation impairs adipogenesis and potentiates a lean phenotype in vivo. Stem Cells. 2012; 30:1477-85. [PubMed: 22511293]

49. Pignolo RJ, Xu M, Russell E, et al. Heterozygous inactivation of Gnas in adipose-derived mesenchymal progenitor cells enhances osteoblast differentiation and promotes heterotopic ossification. J Bone Miner Res. 2011; 26:2647-55. [PubMed: 21812029]

50. Chen M, Chen H, Nguyen A, et al. G(s)alpha deficiency in adipose tissue leads to a lean phenotype with divergent effects on cold tolerance and diet-induced thermogenesis. Cell Metab. 2010; 11:320-30. [PubMed: 20374964]

51. Chen M, Gavrilova O, Zhao WQ, et al. Increased glucose tolerance and reduced adiposity in the absence of fasting hypoglycemia in mice with liver-specific Gs alpha deficiency. J Clin Invest. 2005; 115:3217-27. [PubMed: 16239968]

52. Liu X, Malbon CC, Wang HY. Identification of amino acid residues of Gsalpha critical to repression of adipogenesis. J Biol Chem. 1998; 273:11685-94. [PubMed: 9565589]

53. Wu JY, Aarnisalo P, Bastepe M, et al. Gsalpha enhances commitment of mesenchymal progenitors to the osteoblast lineage but restrains osteoblast differentiation in mice. J Clin Invest. 2011; 121:3492-504. [PubMed: 21804192]

54. Wu J, Purton LE, Rodda SJ, et al. Osteoblastic regulation of B lymphopoiesis is mediated by Gsalpha-dependent signaling pathways. Proc Natl Acad Sci USA. 2008; 105:16976-81. [PubMed: 18957542]

55. Soriano P. Generalized lacZ expression with the ROSA26 Cre reporter strain. Nat Genet. 1999; 21:70-1. [PubMed: 9916792]

56. Muzumdar MD, Tasic B, Miyamichi K, Li L, Luo L. A global double- fluorescent Cre reporter mouse. Genesis. 2007; 45:593-605. [PubMed: 17868096]

57. Yang D, Guo J, Divieti P, Shioda T, Bringhurst FR. CBP/p300-interacting protein CITED1 modulates parathyroid hormone regulation of osteoblastic differentiation. Endocrinology. 2008; 149:1728-35. [PubMed: 18187554]

58. Aubin JE. Osteoprogenitor cell frequency in rat bone marrow stromal populations: role for heterotypic cell-cell interactions in osteoblast differentiation. J Cell Biochem. 1999; 72:396-410. [PubMed: 10022521]

59. Bastepe M, Weinstein LS, Ogata N, et al. Stimulatory G protein directly regulates hypertrophic differentiation of growth plate cartilage in vivo. Proc Natl Acad Sci USA. 2004; 101:14794-9. [PubMed: 15459318]

60. Seale P, Bjork B, Yang W, et al. PRDM16 controls a brown fat/skeletal muscle switch. Nature. 2008; 454:961-7. [PubMed: 18719582]

61. Kajimura S, Seale P, Kubota K, et al. Initiation of myoblast to brown fat switch by a PRDM16-C/ EBP-beta transcriptional complex. Nature. 2009; 460:1154-8. [PubMed: 19641492]

62. Cristancho AG, Schupp M, Lefterova MI, et al. Repressor transcription factor 7-like 1 promotes adipogenic competency in precursor cells. Proc Natl Acad Sci USA. 2011; 108:16271-6. [PubMed: 21914845]

63. Bordicchia M, Liu D, Amri EZ, et al. Cardiac natriuretic peptides act via p38 MAPK to induce the brown fat thermogenic program in mouse and human adipocytes. J Clin Invest. 2012; 122:102236. [PubMed: 22307324]

64. Gupta RK, Arany Z, Seale P, et al. Transcriptional control of preadipocyte determination by Zfp423. Nature. 2010; 464:619-23. [PubMed: 20200519]

65. Rosen ED, MacDougald OA. Adipocyte differentiation from the inside out. Nat Rev Mol Cell Biol. 2006; 7:885-96. [PubMed: 17139329]

66. Krings A, Rahman S, Huang S, Lu Y, Czernik PJ, Lecka-Czernik B. Bone marrow fat has brown adipose tissue characteristics, which are attenuated with aging and diabetes. Bone. 2012; 50:54652. [PubMed: 21723971]

67. Kulkarni NH, Halladay DL, Miles RR, et al. Effects of parathyroid hormone on Wnt signaling pathway in bone. J Cell Biochem. 2005; 95:1178-90. [PubMed: 15962290]

68. Tobimatsu T, Kaji H, Sowa H, et al. Parathyroid hormone increases beta-catenin levels through Smad3 in mouse osteoblastic cells. Endocrinology. 2006; 147:2583-90. [PubMed: 16484320] 
69. Wan M, Yang C, Li J, et al. Parathyroid hormone signaling through low-density lipoprotein-related protein 6. Genes Dev. 2008; 22:2968-79. [PubMed: 18981475]

70. Taurin S, Sandbo N, Qin Y, Browning D, Dulin NO. Phosphorylation of beta-catenin by cyclic AMP-dependent protein kinase. J Biol Chem. 2006; 281:9971-6. [PubMed: 16476742]

71. Guo J, Liu M, Yang D, et al. Suppression of Wnt signaling by Dkk1 attenuates PTH-mediated stromal cell response and new bone formation. Cell Metab. 2010; 11:161-71. [PubMed: 20142103]

72. Gesta S, Tseng YH, Kahn CR. Developmental origin of fat: tracking obesity to its source. Cell. 2007; 131:242-6. [PubMed: 17956727]

73. Kalajzic I, Kalajzic Z, Kaliterna M, et al. Use of type I collagen green fluorescent protein transgenes to identify subpopulations of cells at different stages of the osteoblast lineage. J Bone Miner Res. 2002; 17:15-25. [PubMed: 11771662]

74. Bilic-Curcic I, Kronenberg M, Jiang X, et al. Visualizing levels of osteoblast differentiation by a two-color promoter-GFP strategy: type I collagen-GFPcyan and osteocalcin-GFPtpz. Genesis. 2005; 43:87-98. [PubMed: 16149065]

75. Balemans W, Ebeling M, Patel N, et al. Increased bone density in sclerosteosis is due to the deficiency of a novel secreted protein (SOST). Hum Mol Genet. 2001; 10:537-43. [PubMed: 11181578]

76. Brunkow ME, Gardner JC, Van Ness J, et al. Bone dysplasia sclerosteosis results from loss of the SOST gene product, a novel cystine knot-containing protein. Am J Hum Genet. 2001; 68:577-89. [PubMed: 11179006]

77. Fulzele K, Krause DS, Panaroni C, et al. Myelopoiesis is regulated by osteocytes through Gsalphadependent signaling. Blood. 2013; 121:930-9. [PubMed: 23160461]

78. Fazeli PK, Bredella MA, Freedman L, et al. Marrow fat and preadipocyte factor-1 levels decrease with recovery in women with anorexia nervosa. J Bone Miner Res. 2012; 27:1864-71. [PubMed: 22508185]

79. Menagh PJ, Turner RT, Jump DB, et al. Growth hormone regulates the balance between bone formation and bone marrow adiposity. J Bone Miner Res. 2010; 25:757-68. [PubMed: 19821771]

80. Bellido T, Ali AA, Gubrij I, et al. Chronic elevation of parathyroid hormone in mice reduces expression of sclerostin by osteocytes: a novel mechanism for hormonal control of osteoblastogenesis. Endocrinology. 2005; 146:4577-83. [PubMed: 16081646]

81. Keller H, Kneissel M. SOST is a target gene for PTH in bone. Bone. 2005; 37:148-58. [PubMed: 15946907]

82. Yao GQ, Wu JJ, Troiano N, Insogna K. Targeted overexpression of Dkk1 in osteoblasts reduces bone mass but does not impair the anabolic response to intermittent PTH treatment in mice. J Bone Miner Metab. 2011; 29:141-8. [PubMed: 20602130]

83. Wilson HL, McFie PJ, Roesler WJ. Characterization of domains in C/EBPalpha that mediate its constitutive and cAMP-inducible activities. Mol Cell Endocrinol. 2001; 181:27-34. [PubMed: 11476938]

84. Liu Y, Berendsen AD, Jia S, et al. Intracellular VEGF regulates the balance between osteoblast and adipocyte differentiation. J Clin Invest. 2012; 122:3101-13. [PubMed: 22886301]

85. Rashid G, Bernheim J, Green J, Benchetrit S. Parathyroid hormone stimulates the endothelial expression of vascular endothelial growth factor. Eur J Clin Invest. 2008; 38:798-803. [PubMed: 19021696]

86. Liu LF, Shen WJ, Ueno M, Patel S, Kraemer FB. Characterization of age-related gene expression profiling in bone marrow and epididymal adipocytes. BMC Genomics. 2011; 12:212. [PubMed: 21545734] 
A

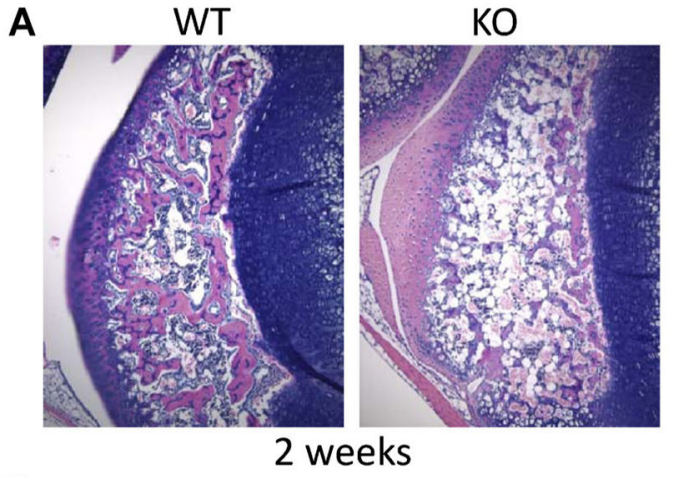

B

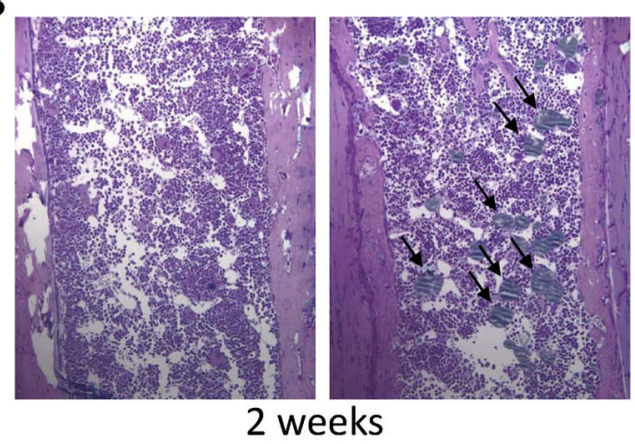

E

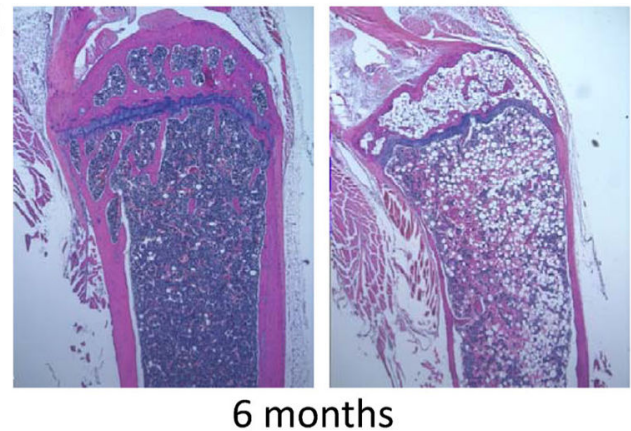

C

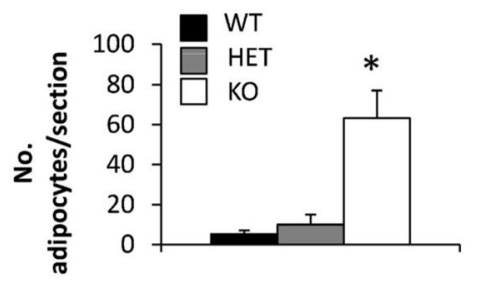

D

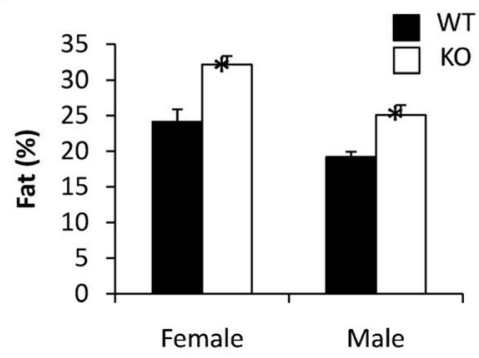

Fig. 1.

$\mathrm{G}_{\mathrm{s}} \mathrm{a}$ OsxKO mice have increased bone marrow adipocytes. (A) Hematoxylin- and eosin(H\&E) stained sections of the secondary ossification center of wild-type (WT) and $\mathrm{G}_{\mathrm{s}} \mathrm{a}$ OsxKO $(\mathrm{KO})$ tibias at 2 weeks. (B) Toluidine blue-stained sections of mid-diaphyseal tibias at 2 weeks. Lipid droplets are marked by arrows. $(C)$ Number of oil red $\mathrm{O}^{+}$cells per sagittal section of tibias in 2-week-old WT, $\mathrm{G}_{\mathrm{s}} \mathrm{a}^{\mathrm{OsxHET}}$ (HET), and KO mice. ${ }^{*} p<0.01(n=$ 4 [WT] and $n=5$ [HET and KO]). (D) Percent fat as measured by DXA in long bones of 3month-old WT and KO mice. ${ }^{*} p<0.02$ ( $n=7-9$ in each group). (E) H\&E-stained sections of proximal tibias from 6-month-old mice. Original magnification $\times 100(A), \times 200(B), \times 40(E)$. 
A

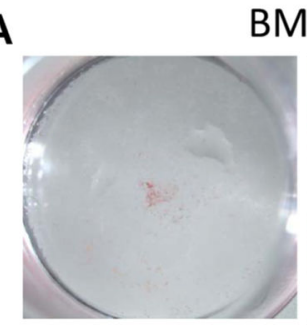

WT

C

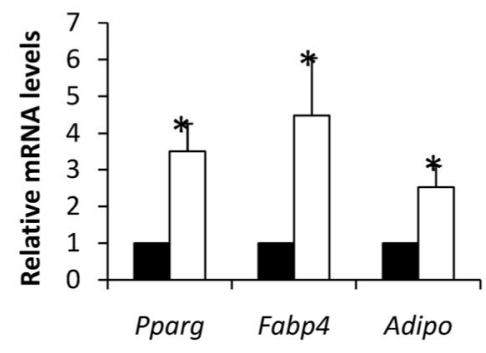

E

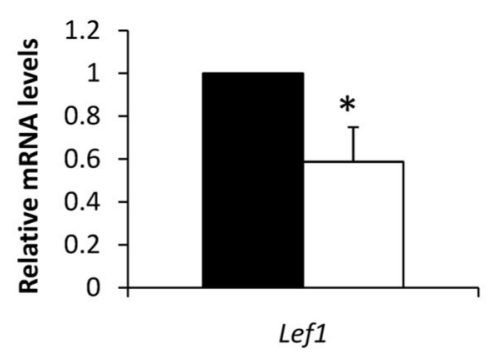

G

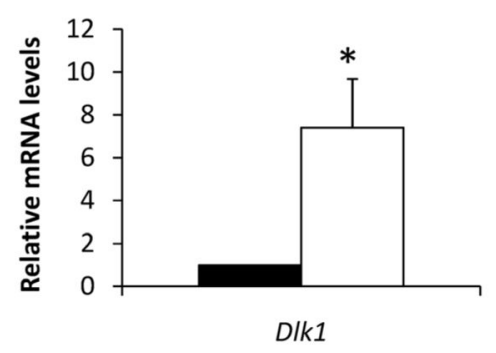

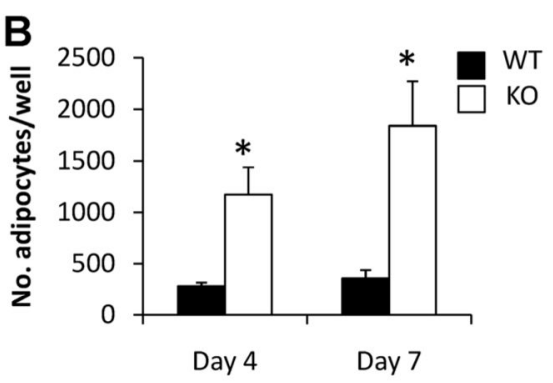

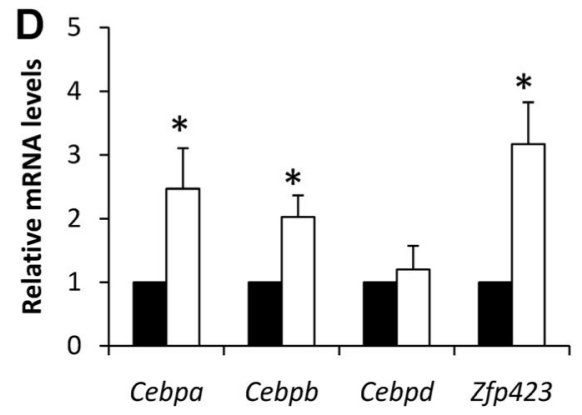

$\mathbf{F}$
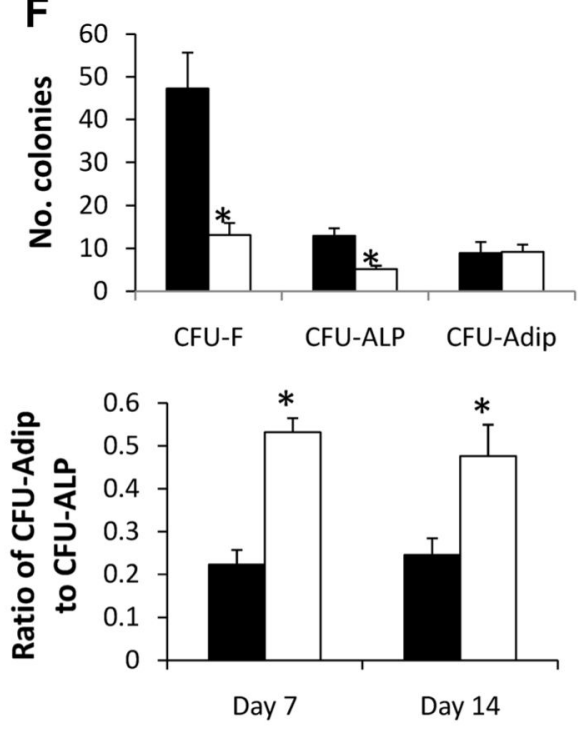

Fig. 2.

$\mathrm{G}_{\mathrm{s}} \mathrm{a}^{\mathrm{OsxKO}}$ BMSCs exhibit enhanced adipogenic differentiation with an increase in frequency of adipocyte precursors. (A) BMSCs from WT and KO littermates were induced to undergo adipogenic differentiation with staining for oil red $\mathrm{O}$ after 7 days. (B) Number of oil red $\mathrm{O}^{+}$ adipocytes per well at days 4 and 7 of adipogenic differentiation. ${ }^{*} p<0.05(n=4$ [WT] and $n=5[\mathrm{KO}])$. (C) mRNA levels for adipogenic markers Pparg, Fabp4, and adiponectin (Adipo) in WT and $\mathrm{G}_{\mathrm{s}} \mathrm{a}$ OsxKO $\mathrm{BMSCs}$ induced to undergo adipogenic differentiation for 7 days. ${ }^{*} p<0.05$ ( $n=3$ experiments). ( $D$ ) Relative mRNA levels for adipogenic transcription factors at day 7 , normalized to WT. ${ }^{*} p<0.05$ ( $n=3$ experiments). (E) mRNA levels of Wnt target gene Lefl at day 0 in WT and $\mathrm{G}_{\mathrm{S}} \mathrm{a}^{\mathrm{OsxKO}}$ BMSCs. ${ }^{*} p<0.05(n=3)$. $(F)$ Number of colony-forming unit-fibroblasts (CFU-F), CFU-alkaline phosphatase (CFU-ALP), and CFU- 
adipocyte (CFU-Adip) mesenchymal, osteoblast, and adipocyte precursors, and ratio of CFU-Adip to CFU-ALP colonies in WT and $\mathrm{G}_{\mathrm{s}} \mathrm{a}$ OsxKO BMSCs. ${ }^{*} p<0.02(n=3$ experiments). ( $G$ ) mRNA levels for $D l k l$ at day 4 of adipogenic differentiation. ${ }^{*} p<0.05$ ( $n$ $=3$ experiments). 
A Calvarial osteoblasts

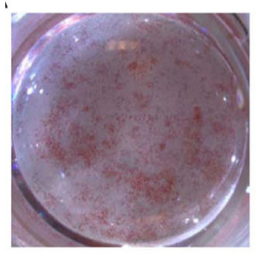

WT

C

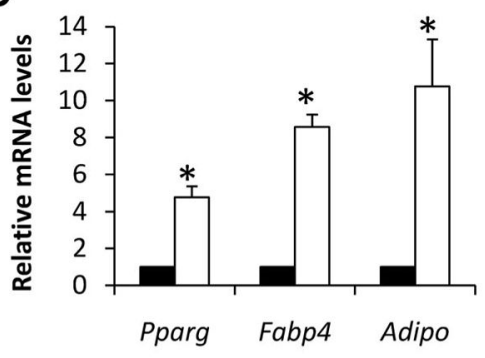

$\mathbf{E}$

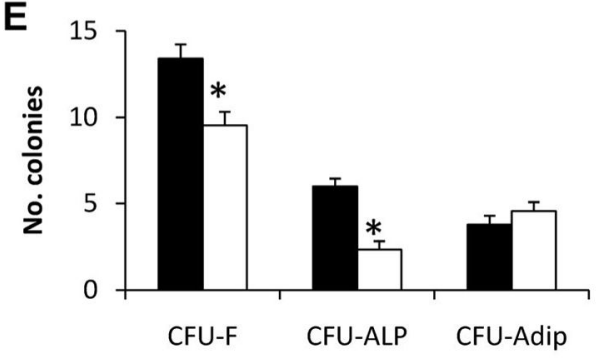

B

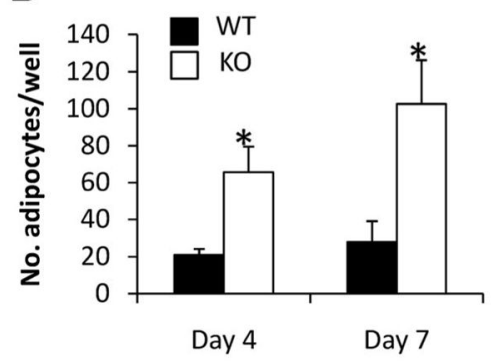

D

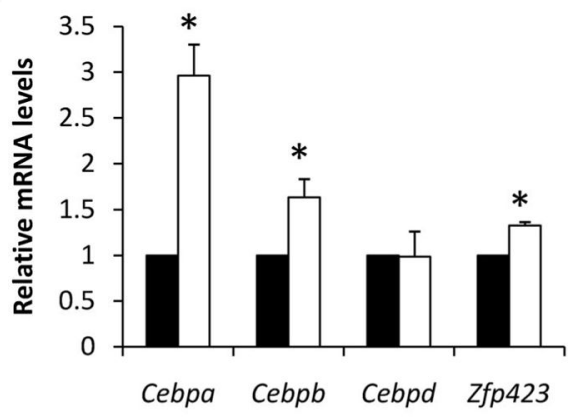

$\mathbf{F}$

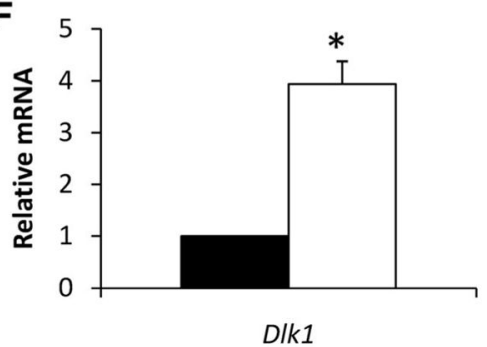

Fig. 3.

$\mathrm{G}_{\mathrm{s}} \mathrm{a}$ OsxKO calvarial osteoblasts exhibit increased adipogenic differentiation. (A) Calvarial osteoblasts from WT and KO littermates were subjected to adipogenic differentiation and stained with oil red O. (B) Number of adipocytes per well at 4 and 7 days of adipogenic differentiation. ${ }^{*} p<0.05$ ( $n=3$ experiments). $(C, D)$ mRNA levels for markers of adipogenic differentiation at day $4 .{ }^{*} p<0.05$ ( $n=3$ experiments). $(E)$ Numbers of CFU-F, CFU-ALP, and CFU-Adip in WT and $\mathrm{G}_{\mathrm{s}} \mathrm{a}$ OsxKO calvarial osteoblasts. ${ }^{*} p<0.005(n=3) .(F)$ mRNA levels for Dlkl at 4 days of adipogenic differentiation. ${ }^{*} p<0.001$ ( $n=3$ experiments). 


\section{BMSCs}
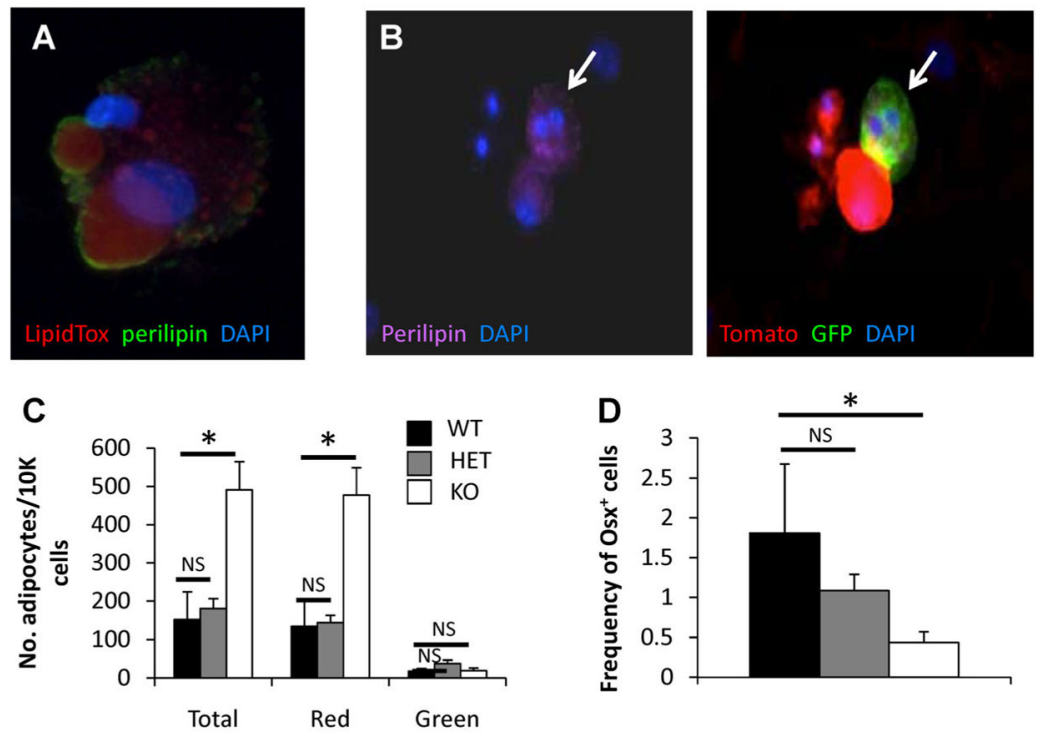

Fig. 4.

Bone marrow osterix ${ }^{+}$osteoprogenitors can become adipocytes in vitro. (A) Differentiation of bone marrow stromal cells into lipid-containing adipocytes was confirmed by co-staining for LipidTox and perilipin. (B) BMSCs from $\mathrm{G}_{\mathrm{s}} \mathrm{a}^{\mathrm{OsxKO}} ; \mathrm{mTmG}$ mice were subjected to adipogenic differentiation and adipocytes identified by expression of perilipin (purple, left panel). The same cells were then visualized for expression of Tomato (not Osx-expressing) versus GFP (Osx-expressing, right panel). The arrow marks the same cell in each panel. $(C)$ Number of adipocytes among bone marrow stromal cells that express Tomato (red) versus GFP (green) for $\mathrm{G}_{\mathrm{s}} \mathrm{a}^{\text {OsxWT }}, \mathrm{G}_{\mathrm{s}} \mathrm{a}^{\text {OsxHET}}$, and $\mathrm{G}_{\mathrm{s}} \mathrm{a}^{\text {OsxKO }}$ littermates. ${ }^{*} p<0.05(n=3$ [WT], $n$ $=7[\mathrm{HET}]$, and $n=8[\mathrm{KO}]), \mathrm{NS}=$ not significant. $(D)$ Frequency of total $\mathrm{GFP}^{+}$descendants of Osx-expressing osteoprogenitors. 
A

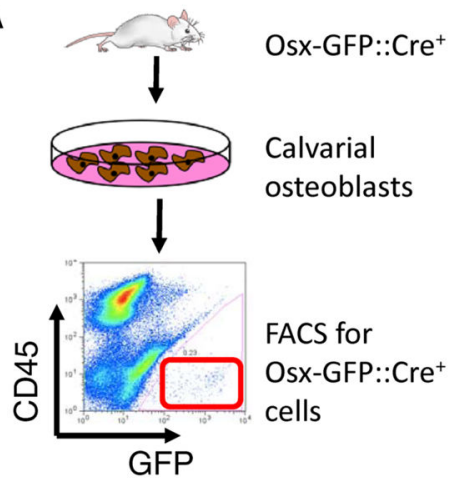

B

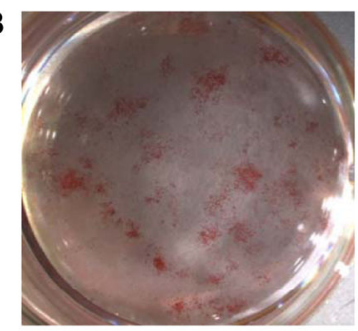

C

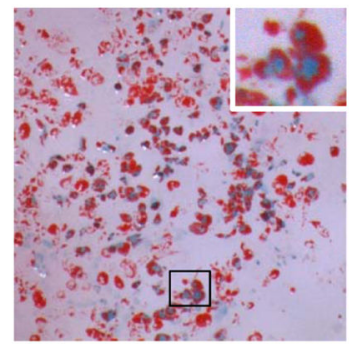

D
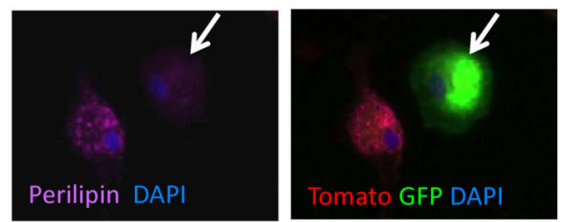

Calvarial osteoblasts
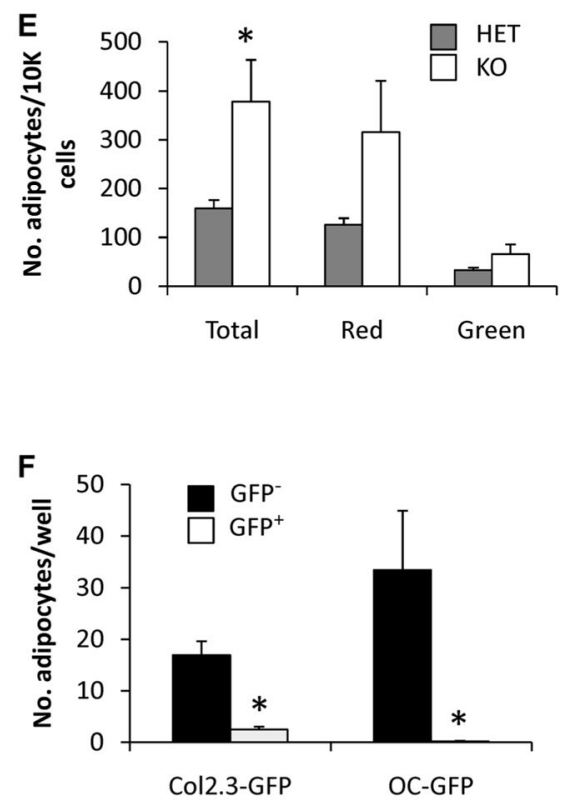

Fig. 5.

Committed osteoprogenitors retain adipogenic potential. (A) FACS-sorting of Osx-GFP ${ }^{+}$ calvarial osteoblasts. (B) Osx-GFP ${ }^{+}$osteoblasts were differentiated under adipogenic conditions and stained with oil red O. (C) X-gal and oil red $\mathrm{O}$ staining of calvarial osteoblasts from $\mathrm{G}_{\mathrm{s}} \mathrm{a}{ }^{\mathrm{OsxKO}} ; \mathrm{R} 26$ mice differentiated under adipogenic conditions. $(D)$ Adipocytes from $\mathrm{G}_{\mathrm{s}} \mathrm{a}^{\mathrm{OsxKO}} ; \mathrm{mTmG}$ mice were identified by expression of perilipin (purple, left panel). Visualization for expression of Tomato and GFP (right panel) demonstrates that adipocytes arise from both Osx-negative (red) and Osx-positive (right) precursors in calvarial osteoblast preparations. The arrow marks the same cell in each panel. $(E)$ Frequency of adipocytes among $\mathrm{G}_{\mathrm{s}} \mathrm{a}^{\mathrm{OsxHET}}$ and $\mathrm{G}_{\mathrm{s}} \mathrm{a}^{\mathrm{OsxKO}}$ calvarial osteoblast cells that express Tomato (red) and GFP (green). ${ }^{*} p<0.05(n=4)$. $(F)$ Number of oil red $\mathrm{O}^{+}$ adipocytes among FACS-sorted Col2.3::GFP ${ }^{-}$versus $\mathrm{GFP}^{+}$and $\mathrm{OC}:: \mathrm{GFP}^{-}$versus $\mathrm{GFP}^{+}$ cells. ${ }^{*} p<0.05$ ( $n=3$ experiments). 


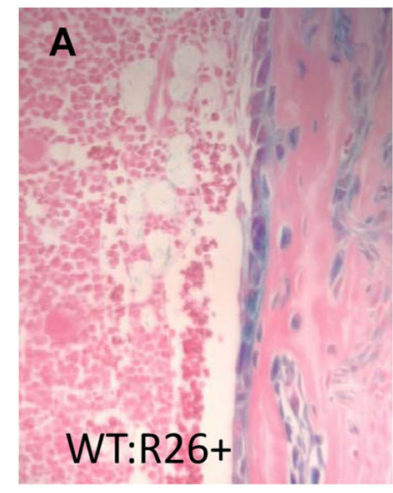

C

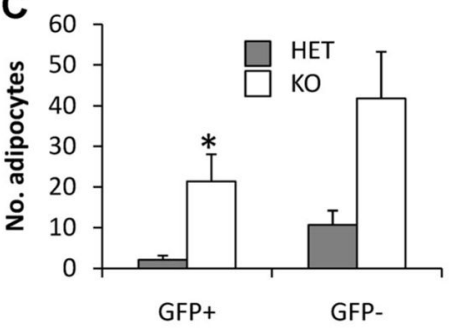

D

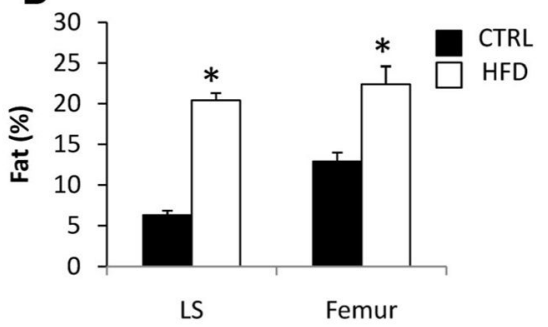

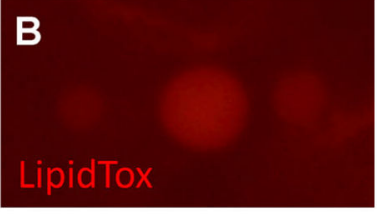
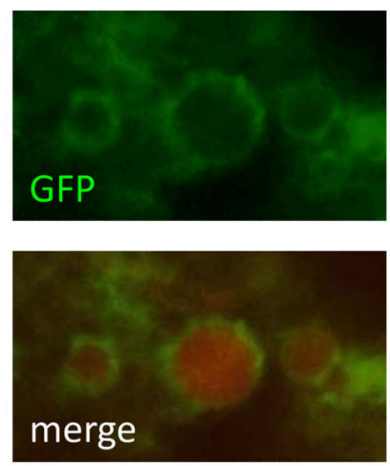

E

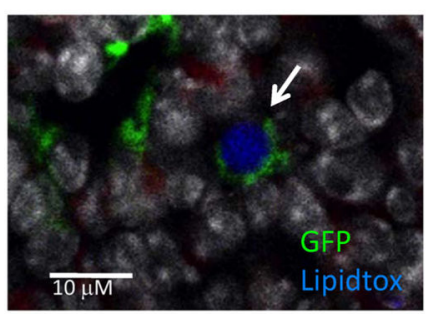

Fig. 6.

Osterix ${ }^{+}$osteoprogenitors can become bone marrow adipocytes in vivo. (A) X-gal and eosinstained sections from 1-week-old WT;R26 and KO;R26 tibia. (B) LipidTox ${ }^{+} \mathrm{GFP}^{+}$ adipocytes can be identified in the bone marrow of $\mathrm{G}_{\mathrm{s}} \mathrm{a}^{\mathrm{OsxKO}} ; \mathrm{mTmG}$ mice. $(C)$ Number of red $\left(\mathrm{GFP}^{-}\right)$and green $\left(\mathrm{GFP}^{+}\right)$adipocytes per sagittal section of tibias in 2-week-old $\mathrm{G}_{\mathrm{s}} \mathrm{a}^{\mathrm{OsxHET}}$;mTmG and $\mathrm{G}_{\mathrm{s}} \mathrm{a}^{\mathrm{OsxKO}} ;$ mTmG mice. ${ }^{*} p<0.01$ ( $n=3$ each [HET and KO]). (D) Percent fat by DXA in control mice fed a high-fat diet for 4 weeks. ${ }^{*} p<0.05$ ( $n=3-5$ mice). (E) Adipocyte (arrow) derived from an Osx1-GFP ${ }^{+}$precursor in WT;mTmG mice fed a high-fat diet. 


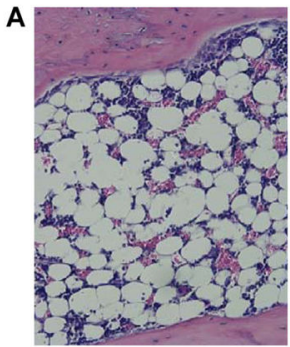

WT
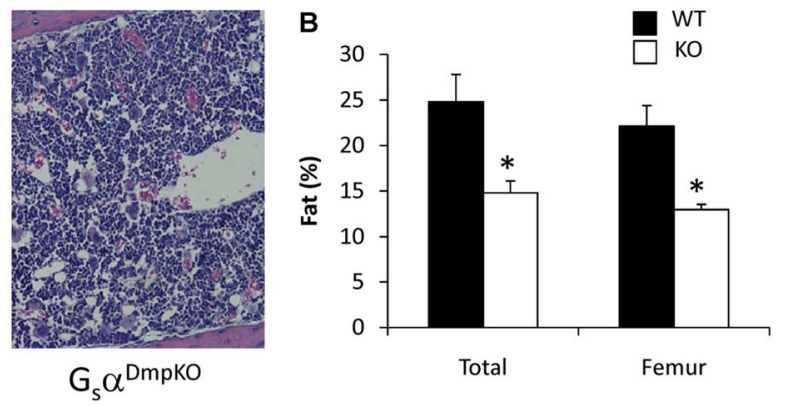

Fig. 7.

Marrow fat is not increased with deletion of $\mathrm{G}_{\mathrm{s}} \mathrm{a}$ from osteocytes. (A) H\&E-stained sections of distal tibias from 5-month-old WT and $\mathrm{G}_{\mathrm{s}} \mathrm{a}$ DmpKO females. $(B)$ Percent fat by DXA in control WT and $\mathrm{G}_{\mathrm{S}} \mathrm{a}^{\text {DmpKO}}$ females. ${ }^{*} p<0.05$ ( $n=5[\mathrm{WT}]$ and $\left.n=4[\mathrm{KO}]\right)$. 